\title{
Potassium Permanganate Dye Removal from Synthetic Wastewater Using A Novel, Low-Cost Adsorbent, Modified from The Powder of Foeniculum Vulgare Seeds
}

Suhair Bani-Atta ( $\sim$ s_bantatta@ut.edu.sa )

University of Tabuk https://orcid.org/0000-0001-9473-8089

\section{Research Article}

Keywords: Low-cost adsorbent, Modification, Synthetic Wastewater, Potassium permanganate Removal.

Posted Date: November 3rd, 2021

DOI: https://doi.org/10.21203/rs.3.rs-1016827/v1

License: (c) (i) This work is licensed under a Creative Commons Attribution 4.0 International License.

Read Full License

Version of Record: A version of this preprint was published at Scientific Reports on March 16th, 2022. See the published version at https://doi.org/10.1038/s41598-022-08543-z. 
Potassium permanganate dye removal from synthetic wastewater using a novel, low-cost adsorbent, modified from the powder of Foeniculum Vulgare seeds

Department of Chemistry, Faculty of Science, University of Tabuk, Tabuk 71491, Saudi Arabia

*Corresponding author. Suhair. A. Bani-Atta. Tel: +966- 535817359, E-mail address: s_bantatta@yahoo.com, $\underline{\text { s_bantatta@ut.edu.sa }}$

9 Abstract

Seeds powder of Foeniculum vulgare (FVE) was used to prepare a novel adsorbent, the new

11 adsorbent was characterized and its ability to eliminate potassium permanganate $\left(\mathrm{KMnO}_{4}\right)$ was

12 examined. The impact of $\mathrm{KMnO}_{4}$ concentration, adsorbent dose, contact temperature, contact

13 time, and solution $\mathrm{pH}$ on the adsorption performance was also investigated. The experimental

14 data of this adsorption was analyzed by different kinetic and isotherm models. As Constants of 15 thermodynamic $\Delta \mathrm{G}^{\circ}, \Delta \mathrm{H}^{\circ}$, and $\Delta \mathrm{S}^{\circ}$ have been also evaluated. Surface area, pore volume, and 16 pore size of the modified Foeniculum vulgare seeds powder (FVESP) adsorbent were determined 17 as $0.6806 \mathrm{~m}^{2} \mathrm{~g}^{-1}, 0.00215 \mathrm{~cm}^{3} \mathrm{~g}^{-1}$, and $522.063 \AA$, as $\mathrm{pH}_{\mathrm{ZPC}}$ of oxalic acid FVESP (Ox- FVESP) was stated to be 7.2 . The $\mathrm{R}^{2}$ values obtained from applying different isotherm and kinetic models

19 (0.999 and 0.996) showed that the adsorption performance of $\mathrm{KMnO}_{4}$ follows the Langmuir and 20 Pseudo $2^{\text {nd }}$ order models. Furthermore, high adsorption capacities of $1111.11,1250.00$, and $21 \quad 1428.57(\mathrm{mg} / \mathrm{g})$ were achieved at three temperatures that were used in this study. Constants of 22 thermodynamic $\Delta \mathrm{G}^{\circ}, \Delta \mathrm{H}^{\circ}$, and $\Delta \mathrm{S}^{\circ}$ values indicate chemical and spontaneous adsorption at the 23 adsorbent surface.

24 Keywords: Low-cost adsorbent, Modification, Synthetic Wastewater, Potassium permanganate 25 Removal. 


\section{Introduction}

27 Potassium permanganate $\left(\mathrm{KMnO}_{4}\right)$ is a highly strong oxidizing agent that is commonly used for

28

29

30

31

32 water purification from numerous pollutants, mainly for the destruction of compounds that causing undesirable taste, odor, and color for the treated water [1]. Remarkably, permanganate is still one of the most oxidizing chemicals ever applied to remove each iron, manganese, and arsenic from water [2, 3], In addition to its great ability to oxidize cyanide, phenols, and organic compounds [4-8].

Recently, many studies reported that the excessive exposure to permanganate may cause acute problems of the nervous system, irritation of the skin and eye, Furthermore, it was stated that the manganese has significant toxicity towards the liver and kidneys [9, 10]. Therefore many techniques and methods have been applied for $\mathrm{KMnO}_{4}$ removal from the contaminated water. For instance, fluidized-bed crystallization method was used [11], concerning the ease of preparation and use, in addition to the high capacity to get rid of permanganate from wastewater adsorption is one of the most extensively utilized processes with different adsorbents [1], activated carbon is a common adsorbent that used for adsorption of $\mathrm{KMnO}_{4}$ from polluted water due to its high adsorption efficiency [12].

To remove potassium permanganate molecules from polluted aqueous solutions by adsorption a lot of activated carbon adsorbents were prepared using shells of coconut [12], corn cob, and animal bone were also applied [13], sulfuric acid modification of activated carbon, and activated charcoal have been used too $[1,14]$. More recently, Nanoparticles of metallic oxides have been used to remediate effluent from various dyes [15-21], Copper sulfide nanoparticles were used as dynamic adsorbents to treat the synthetic wastewater from potassium permanganate ions [22]. 
48 Despite the great performance and significant efficiency of activated carbon and metallic oxides

49 Nanoparticles, its requirements and conditions of preparation are rather difficult and expensive.

50 Thus, prompted the researchers to use low-cost materials within their areas and applied them as

51 adsorbents for permanganate ions adsorption. For instance, sage [23] Neem [24], Nitraria retusa

52 [25], and Ocimum basilicum [26] were used as low-cost sorbents to remove Permanganate

53 anions from synthetic samples.

54 Foeniculum vulgare plant (FVE) is well-known by fennel in many countries and as shamr in

55 Saudi Arabia, mainly used as food and tea flavored and considered as a flavored spice, its seeds

56 were used as antitumor [27], antimicrobial [28], and antioxidant [29]. Gold nanoparticles based

57 on seeds extract of fennel FVE was synthesized and its catalytic activity against rhodamine B

58 and methylene blue days were examined [30], $\mathrm{V}_{2} \mathrm{O}_{5}-\mathrm{Fe}_{2} \mathrm{O}_{3}$ nanocomposites from stem powder of

59 FVE have been produced and the catalytic performance of nanocomposites particles was

60 assessed for reduction of 4-nitrophenol [31].

61 Up to now, no adsorbent based on FVE seeds (FVES) was prepared in any form and applied to

62 eliminate the hazardous dyes from water even permanganate ions, despite the excellent medical

63 properties of FVE herb, in addition to its widespread over the world. Therefore, this research

64 mainly aimed to prepare a new adsorbent from seeds of FVE and to investigate the adsorbent

65 performance toward eliminating $\mathrm{KMnO}_{4}$ from polluted water. Thermodynamics, Kinetics, and

66 isotherms parameters will also be studied. The performance of this adsorption will be also

67 studied through conditions and impacts that could affect on $\mathrm{KMnO}_{4}$ removal experiment, as the

68 adsorption capacity of modified adsorbent for removal of $\mathrm{KMnO}_{4}$ will be critically addressed.

69 To achieve all the desired goals of this work and get the best results, unmodified samples from

70 FVES have been synthesized and the modification has been also carried by zinc chloride, copper 
71 sulfide, and oxalic acid; both types of samples have been characterized and examined as

72 adsorbents for $\mathrm{KMnO}_{4}$ removal from water, to choose the best adsorbent, the adsorption

73 performances have been compared, then all the $\mathrm{KMnO}_{4}$ adsorption experimental factors and 74 conditions of selected adsorbent were tested.

\section{2. Materials and Methodology}

\section{$76 \quad 2.1$ Materials}

77 Seeds of FVE were obtained from a local market in Tabuk City, KSA. All chemicals that were 78 used in this work were obtained from Sigma-Aldrich with purity of (37\%) for hydrochloric acid, $79 \geq 97 \%$ for sodium hydroxide $\geq 97 \%$ for zinc chloride, $\geq 99: 99 \%$ for oxalic acid, $\geq 99: 99 \%$ for 80 copper sulfide, and $\geq 99: 00 \%$ for sodium carbonate.

\section{2.2. Methodology}

\section{$82 \quad$ 2.2.1. Preparation and Modification of FVESP}

83 The FVE seeds were washed with distilled water several times and then dried overnight, after 84 that the powder from the FVE seeds (FVESP) was obtained by an electric grinder. A sample of $85100 \mathrm{~g}$ was refluxed for $180 \mathrm{~min}$ with $1 \mathrm{~L}$ of oxalic acid $(20 \% \mathrm{w} / \mathrm{w})$, afterwards, the mixture was 86 allowed to cool at room temperature. The sold part was separated by filtration, to get rid of any 87 excess amount of oxalic acid; the solid was heated for $90 \mathrm{~min}$ with $250 \mathrm{~mL}$ of $2 \mathrm{M}$ hydrochloric acid. Then, the filtration of the new mixture was done many times and rinsed with distilled water

89 to have a clean solid, to get rid of any water present in the sample; the solid was left in the oven 90 for $30 \mathrm{~h}$ at $130^{\circ} \mathrm{C}$. Finally, to ensure the homogeneity of the sample, the dry solid was grinded 91 and sieved, and the resulted adsorbent labeled as Ox-FVESP. 
92 The same procedure was repeated with mixtures containing $100 \mathrm{~g}$ of FVESP with1 L of $20 \%$

93 w/w acidic solution of zinc chloride, and $100 \mathrm{~g}$ FVESP with a mixture of $20 \%$ w/w acidic

94 solution of zinc chloride and $50 \mathrm{~g}$ of copper sulfide. The resulted adsorbents were labeled also

95 Zn-FVESP, and Zn/Cu- FVESP.

\subsubsection{Characterization of FVESP adsorbents}

97 To recognize the surface morphology of the modified and unmodified FVESP adsorbents SEM 98 instrument was used at a $10 \mathrm{kV}$ accelerating voltage. And to determine the surface adsorbents' 99 functional groups, the FT-IR instrument (Nicolet iS5 of Thermo Scientific FT-IR, USA) was 100 carried out. The surface area and porosity of each adsorbent were estimated using BET (NOVA1012200 Ver. 6.11) technology for 22 hours and $77.35 \mathrm{~K}$. In addition, $40 \mathrm{~mL}$ of $0.05 \mathrm{M} \mathrm{Na}_{2} \mathrm{CO}_{3}$ 102 solutions varying with $2,4,6,8$, and 10 initial values of $\mathrm{pH}_{\mathrm{i}}$ have been mixed in a $150 \mathrm{~mL}$ 103 plastic container with $0.2 \mathrm{~g}$ of the idealistic adsorbent. After shaking all containers for 26 hours $104175 \mathrm{rpm}$ and $27^{\circ} \mathrm{C}$ conditions in a shaker incubator, filtration of each was done, then using a $\mathrm{pH}$ 105 meter, the final $\mathrm{pH}\left(\mathrm{pH}_{\mathrm{f}}\right)$ of each solution was determined. Finally, to determine the $\mathrm{pH}_{\mathrm{ZPC}}$ value 106 of this adsorbent, the values of $\left(\mathrm{pH}_{\mathrm{i}}-\mathrm{pH}_{\mathrm{f}}\right)$ have been calculated and graphed against the $\mathrm{pH}_{\mathrm{i}}$ 107 values.

\subsubsection{Experiments on Adsorption}

\subsubsection{The Idealistic Adsorbent Identification}

110 To determine the superlative as well as the most efficient adsorbent developed in the current 111 study for $\mathrm{KMnO}_{4}$ removal from synthetic aqueous samples, $20 \mathrm{~mL}$ of $100 \mathrm{mg} / \mathrm{L} \mathrm{KMnO}_{4}$ solution 112 concentration was combined with $0.03 \mathrm{~g}$ of FVESP in a $30 \mathrm{~mL}$ amber bottle. A shaker incubator 113 was used for 30 hours to stirrer the sealed amber bottle at $27^{\circ} \mathrm{C}$ and $180 \mathrm{rpm}$. After that, the 
114 mixture was filtered; The Jenway UV-6800 UV-Vis spectrophotometer was used at $525 \mathrm{~nm}$ to 115 measure the balanced concentration of $\mathrm{KMnO}_{4}$ in the filtrate. The same procedure was repeated 116 with Ox- FVESP, Zn- FVESP, and Zn/Cu- FVESP adsorbents for the $\mathrm{KMnO}_{4}$ adsorption. 117 Equations (I) and (II) were used to calculate the $\mathrm{KMnO}_{4}$ percentage removal percent $\% \mathrm{R}$ and the 118 quantities of $\mathrm{KMnO}_{4}$ adsorbed at equilibrium $\mathrm{Q}_{\mathrm{e}}\left(\mathrm{mg} \mathrm{g}^{-1}\right)$ by both modified and unmodified 119 adsorbents.

$$
\begin{gathered}
\% \boldsymbol{R}=\frac{\boldsymbol{C}_{\mathrm{o}}-\boldsymbol{C}_{e}}{\boldsymbol{C}_{\mathrm{o}}} \mathbf{1 0 0} \% \\
Q_{e}=\frac{V}{m}\left(C_{\mathrm{o}}-C_{e}\right)
\end{gathered}
$$

120 Where $\mathrm{C}_{0}$ is the $\mathrm{KMnO}_{4}$ initial concentration and $\mathrm{C}_{\mathrm{e}}$ is the $\mathrm{KMnO}_{4}$ final concentration, $\mathrm{m}$, and $\mathrm{V}$ 121 are the mass of adsorbent $(\mathrm{g})$, and $\mathrm{KMnO}_{4}$ solution volume (L), respectively.

\subsubsection{Experimental Conditions impact}

123 Batch experiments have been conducted to observe and identify the most significant factors that 124 affect $\mathrm{KMnO}_{4}$ adsorption experiments by ideal adsorbent Ox- FVESP, such as concentration of $125 \mathrm{KMnO}_{4}\left(10-1400 \mathrm{mg} \mathrm{L}{ }^{-1}\right)$, contact time (0-320 min), the dosage of Ox- FVESP adsorbent 126 (0.005- $0.035 \mathrm{~g})$, the adsorption temperature $\left(27-57^{\circ} \mathrm{C}\right)$, and the $\mathrm{pH}(1.5-11.5)$. All of the Batch 127 experiments have been done in $30 \mathrm{ml}$ amber bottles by adding $20 \mathrm{~mL}$ of $\mathrm{KMnO}_{4}$ solution to 128 enough amounts from Ox-FVESP. A shaker incubator at $180 \mathrm{rpm}$ was used to shake all sealed 129 amber bottles for a required time, followed by filtration of each mixture, and the remaining 130 concentrations of $\mathrm{KMnO}_{4}$ were measured as mentioned previously in part 4.2.1 
131 To compute the adsorbed amount of $\mathrm{KMnO}_{4}$ at equilibrium $\left(\mathrm{Q}_{\mathrm{e}}, \mathrm{mg} \mathrm{g}^{-1}\right)$ by the Ox- FVESP

132 adsorbent and time $\mathrm{t}\left(\mathrm{Q}_{\mathrm{t}}, \mathrm{mg} \mathrm{g}^{-1}\right)$ equations (II) and (III) were applied.

$$
Q_{t}=\frac{V}{m}\left(C_{\mathrm{o}}-C_{t}\right)
$$

133 Where $\mathrm{Ct}_{\mathrm{t}}\left(\mathrm{mg}^{\mathrm{L}} \mathrm{L}^{-1}\right)$ is the $\mathrm{KMnO}_{4}$ concentration of at contact time.

\subsubsection{Temperature impact and isotherm studies}

135 The outcomes obtained from Section 2.2.3.2 for $10-1400 \mathrm{mg} / \mathrm{L} \mathrm{KMnO}_{4}$ solutions by $0.02 \mathrm{~g}$ by 136 Ox- FVESP adsorbent at $26 \mathrm{~h}$ contact time and three different temperatures $\left(27,42\right.$, and $\left.57^{\circ} \mathrm{C}\right)$ 137 and $190 \mathrm{rpm}$ have been analyzed according to the three isotherm models, Langmuir, Freundlich, 138 and Temkin linear forms, equations (IV, V, VI) respectively. The parameter of equilibrium $\mathrm{R}_{\mathrm{L}}$ 139 value of the Langmuir isotherm model was also evaluated according to Equation (VII).

$$
\begin{aligned}
& \frac{C_{e}}{q_{e}}=\frac{1}{q_{\max } K_{L}}+\frac{C_{e}}{q_{\max }} \\
& \ln q_{e}=\ln K_{F}+\frac{1}{n} \ln C_{e} \\
& q_{e}=B_{1} \ln K_{T}+B_{1} \ln C_{e} \\
& R_{L}=\frac{1}{1+K_{L} C_{0}}
\end{aligned}
$$

140 Where $\mathrm{C}_{\mathrm{o}}$ is the maximum initial concentration of $\mathrm{KMnO}_{4}$ and $\mathrm{K}_{\mathrm{L}}$ is the constant of Langmuir,

$141 \mathrm{~K}_{\mathrm{F}}$ is the constant of Freundlich, and $\mathrm{K}_{\mathrm{T}}$ is the constant Temkin. $\mathrm{q}_{\max }(\mathrm{mg} / \mathrm{g})$ is the maximum 
142 capacity of adsorption. B1 and $\mathrm{n}$ are constants of the adsorption heat and the intensity of 143 adsorption, respectively.

\section{$144 \quad 2.2 .3 .4$. Contact time impact and Kinetic studies}

145 The experimental data obtained from the adsorption Section 2.2.3.2, adsorption of $\mathrm{KMnO}_{4}$ by 146 Ox- FVESP with a concentration of 50, 100, and $200 \mathrm{mg} \mathrm{L}^{-1}$ at several times from 0 to $320 \mathrm{~min}$ 147 and $27^{\circ} \mathrm{C}$ and $190 \mathrm{rpm}$ have been analyzed by three of different kinetic models. Equations 148 (VIII), (IX), and (X), Pseudo $1^{\text {st }}$ order, Pseudo $2^{\text {nd }}$ order, and Intraparticle diffusion, 149 correspondingly. Then, the achieved results have been used to the study each of the conducted 150 time impact, rate, and mechanism of $\mathrm{KMnO}_{4}$ adsorption by Ox- FVESP adsorbent.

$$
\begin{aligned}
& \log \left(Q_{e}-Q_{t}\right)=\log Q_{e}-K_{1} \frac{t}{2.303} \\
& \frac{t}{Q_{t}}=\frac{1}{K_{2} Q^{2}{ }_{e}}+\frac{t}{Q_{e}} \\
& Q_{t}=K_{d i f} \sqrt{t}+C
\end{aligned}
$$

$151 \mathrm{Q}_{\mathrm{t}}\left(\mathrm{mg} \mathrm{g}^{-1}\right)$ : the amount of adsorbed $\mathrm{KMnO}_{4}$ at time $\mathrm{t}, \mathrm{Q}_{\mathrm{e}}$ : the amount of adsorbed $\mathrm{KMnO}_{4}$ at 152 equilibrium, $\mathrm{K}_{1}(1 / \mathrm{min})$ : rate constants of Pseudo $1^{\text {st }}$ order, $\mathrm{K}_{2}$ : $\left(\mathrm{g} \mathrm{mg}^{-1} \mathrm{~min}^{-1}\right)$ rate constants of 153 the $2^{\text {nd }}$ order. $\mathrm{K}_{\mathrm{dif}}\left(\mathrm{mg} \mathrm{g}^{-1} \mathrm{~min}^{-1}\right)^{1 / 2}$ and $\mathrm{C}$ are rate constants of intraparticle diffusion.

\section{$154 \quad$ 2.2.3.5. Thermodynamic experiment}

155 Constants of thermodynamic $\Delta \mathrm{G}^{\circ}, \Delta \mathrm{H}^{\circ}$, and $\Delta \mathrm{S}^{\circ}$ have been also evaluated from the outcomes of 156 Section 2.2.3.2 for adsorption of 500, 700, 1000, and $1200 \mathrm{mg} \mathrm{L}^{-1} \mathrm{KMnO}_{4}$ solutions according to 157 equations (XI) and (XII). 


$$
\operatorname{Ln}\left(\frac{Q_{e}}{C e}\right)=-\frac{\Delta \mathrm{H}^{\circ}}{R T}+\frac{\Delta S^{\circ}}{R}
$$

$$
\Delta G^{\circ}=\Delta \mathrm{H}^{\circ}-T \Delta S^{\circ}
$$

Where $\Delta \mathrm{S}^{\circ}, \Delta \mathrm{G}^{\circ}$, and $\Delta \mathrm{H}^{\circ}$ are the change in standard entropy, change in standard free energy, and is the change in standard enthalpy, $\mathrm{T}$ and $\mathrm{R}$ are the adsorption temperature of $(\mathrm{K})$ and universal gases constant $(8.314 \mathrm{~J} / \mathrm{K} \mathrm{mol})$, respectively.

\section{Results and Discussion}

\subsection{FVESP Characterization}

The FT-IR spectra of four samples of modified and unmodified FVESP are revealed in Figures 1. It can be observed from the figure that the unmodified FVESP sample has six peaks at 1060 $\mathrm{cm}^{-1}$ for $\mathrm{C}-\mathrm{O}$ stretching, $1118 \mathrm{~cm}^{-1}$ for C-O stretching of a secondary alcohol, $1025 \mathrm{~cm}^{-1}$ for $\mathrm{C}-\mathrm{F}$ stretch Aliphatic fluoro compounds, $1590 \mathrm{~cm}^{-1}$ for $\mathrm{C}=\mathrm{C}$ stretching, $2870 \mathrm{~cm}^{-1}$ and $2940 \mathrm{~cm}^{-1}$ for stretching the $\mathrm{C}-\mathrm{H}$ alkane, and $3360 \mathrm{~cm}^{-1}$ for hydrogen bond stretching of the $\mathrm{O}-\mathrm{H}$. Figure 1 illustrates also that the modified Zn- FVESP, and Zn/Cu- FVESP adsorbents showed the same peaks with a slight shift, while in the case of Ox- FVESP sample, many peaks developed (Figure 1), and these bands are $1190 \mathrm{~cm}^{-1}, 1320 \mathrm{~cm}^{-1}$, and $1620 \mathrm{~cm}^{-1}$, The appearance of these bands support the success of the chemical modification process that was carried out for the adsorbent and also confirms the variety of functional groups on the surface of Ox- FVESP, which will have an effective role in permanganate adsorption from the water later.

The spectrum of FVESP, Zn- FVESP, Ox- FVESP, and Zn/Cu- FVESP SEM images are demonstrated in Figures 2(a), 2(b), 2(c), and 2(d), respectively. When comparing the SEM images of modified samples (b), (c), and (d) to the unmodified adsorbent (a), it can be seen that 
179 the surface of the FVESP adsorbent has been significantly transformed by modification 180 procedure, as most of the modified adsorbents pleats have been distorted and their structures

181 became scattered. Furthermore, several heterogeneous holes and pores have appeared on the 182 modified adsorbents surfaces, which improve the adsorption performance. It is also recognized 183 from Figure 2(c) that the density of micropores of the modified adsorbent is more than the rest of 184 the other samples.

185 The relationship between pHi and pHi-pHf is depicted in Figure 3, which shows that $\mathrm{pH}_{\mathrm{ZPC}}$ (the 186 solution $\mathrm{pH}$ when the surface of sorbent has a zero net charge) is 7.2. Meanwhile, the surface 187 charge of the adsorbent will be positive and negative at solution $\mathrm{pH}$ levels lower and higher than 188 7.2, Al-Aoh [25] has previously found similar findings.

189 BET surface analyzer results for the modified and unmodified FVESP samples are listed in table 1901 , Surface Area $\left(\mathrm{m}^{2} \mathrm{~g}^{-1}\right)$, Volume of Pore $\left(\mathrm{cm}^{3} \mathrm{~g}^{-1}\right)$, and Size of Pore $(\AA)$. The table shows that 191 the Ox- FVESP sample achieved the highest surface area $\left(0.6806 \mathrm{~m}^{2} \mathrm{~g}^{-1}\right)$ and size of the pore 192 (522.063 $\AA$ ) compared to the rest of the other samples, The highest values of the surface area and 193 size of pore will positively affect the process of permanganate adsorption on the modified 194 FVESP surface by oxalic acid and prove that the modification process has an important and 195 obvious role.

\subsection{The Idealistic Adsorbent Identification}

197 Figure 4 illustrates the percentage removal for $\mathrm{KMnO}_{4}$ adsorption by four different samples that 198 were synthesized and modified in this work, and it was as the following 80.52 for FVESP, 64.03 199 for Zn- FVESP, 89.36 for Ox- FVESP, and 49.08 for Zn/Cu- FVESP. the percentage removal 200 values show that the Ox- FVESP adsorbent has the greatest percentage among other samples, so, 201 these findings support the Ox- FVESP adsorbent is the best sample for $\mathrm{KMnO}_{4}$ adsorption. Also, 
202 these results were fully consistent with the SEM and BET surface outcomes. As a result, only

203 Ox- FVESP adsorbent was used in the rest of this study.

\section{3.3. Experimental Conditions impact}

\subsubsection{Influence of pH solution}

206 The adsorption performance is greatly influenced by the $\mathrm{pH}$ of the adsorbate solution, degree of 207 ionization, and charge of adsorbent of the dye molecules also impacted by $\mathrm{pH}$. As a result, the 208 impact of this issue was addressed in this study (Figure 5). It is clear from the figure that the qe

$209\left(\mathrm{mg} \mathrm{g}^{-1}\right)$ value was greatly affected by the $\mathrm{pH}$ values, as it was high when $\mathrm{pH}$ values were raised 210 from 1.5 to 7.2 , and this is due to the high attraction between the positive charges of the Ox211 FVESP surface and the $\mathrm{MnO}_{4}^{-}$anions. In contrast, increasing the $\mathrm{pH}$ value over 7.2 has a 212 negative effect on $q e\left(\mathrm{mg} \mathrm{g}^{-1}\right)$ because of the significant repulsion between the negative $\mathrm{MnO}_{4}^{-}$ 213 ions and the negative charges of this adsorbent surface. Like results have been found for the $214 \mathrm{KMnO}_{4}$ elimination by chemically modified sage leaves powder [23].

\section{$215 \quad 3.3 .2$. Impact of Ox- FVESP doses}

216 To specify the ideal mass of Ox- FVESP that will be required for the KMnO4 adsorption the 217 percent removal of $\mathrm{KMnO} 4$ was plotted against Ox- FVESP doses and to investigate the 218 adsorbent dosage impact (Figure 6). The values of percent removal of $\mathrm{KMnO} 4 \% \mathrm{R}$ are 219 improved by increasing the mass of Ox- FVESP from 0.005 to $0.020 \mathrm{~g}$. This rise was caused by 220 the improvement of the active sites on the Ox- FVESP surface, which is related to the adsorbent 221 quantity [33]. Figure 6 shows also the percent R value does not change significantly that when 222 the mass of the adsorbent is increased from $0.020 \mathrm{~g}$ to $0.035 \mathrm{~g}$ because the adsorbent particles 223 will be gathered to form a cluster at high doses [34]. In this study, $0.020 \mathrm{~g}$ of Ox- FVESP was 
224 chosen as the optimal dose. The adsorption of $\mathrm{CR}$ dye by $\mathrm{Zn} / \mathrm{Cu}$-TPLLP adsorbent [22] and

$225 \mathrm{KMnO}_{4}$ on the $\mathrm{CuS}$ surface showed a similar Patten [35].

\section{3.3. Temperature impact and isotherm studies}

227 The impact of initial solution concentration and temperature on the adsorption capacity of this

228 work is demonstrated in figure 7. Figure 7 shows the relationship between the adsorption amount

$229 \mathrm{Q}_{\mathrm{e}}(\mathrm{mg} / \mathrm{g})$ and the concentration of $\mathrm{KMnO}_{4}\left(10-1400 \mathrm{mg} \mathrm{L}^{-1}\right)$ at 27,42 , and $57^{\circ} \mathrm{C}$ temperatures.

230 It can be observed from the figure that rising the temperature of the solution has a positive

231 impact on the adsorption capacity of $\mathrm{KMnO}_{4}$ by Ox- FVESP. And this refers to the decreasing of

$232 \mathrm{KMnO}_{4}$ viscosity with solution temperature increasing, Also, the kinetic energy of the

233 permanganate particles increases with rising the temperature, the same kinetic energy

234 performance for permanganate ions was recorded by neem leaves powder adsorbent [24]. It is

235 also noted from the same figure that the adsorption of permanganate is improved by rising the

236 concentration of $\mathrm{KMnO}_{4}$ from 10 to $1400(\mathrm{mg} / \mathrm{L})$ at the same temperature. And this could be

237 supported by the finding that rising the adsorbate concentration will develop the dynamic force,

238 which lowers the resistance of $\mathrm{KMnO}_{4}$ particles mass movement between the Ox- FVESP

239 surface and adsorbate solution [32]. It is also clear that the adsorbent will be effective even at

$240 \mathrm{KMnO}_{4}$ concentrations higher than $1400(\mathrm{mg} / \mathrm{L})$, and this is refer to the unfilled adsorption sites

241 on the adsorbent surface.

242 Moreover, The outcomes obtained from Section 2.2.3.2 were analyzed according to the isotherm 243 model of Langmuir (Ce against Ce/qe), isotherm model of Freundlich (ln Ce against ln qe), and

244 isotherm model of Temkin (ln Ce against qe) Figure 8 (a, b, and c), the slopes and intercepts of 245 these plots were used to achieve the isotherm parameters and presented in Table 2. Where the 246 experimental results are well fitted by applying the Langmuir isotherm model and the $\mathrm{R}^{2}$ values 
247 were the highest compared with Freundlich and Temkin models Table 2, which approves that the

248 Langmuir model is the best fit for this adsorption. These findings also show that the adsorption

249 of $\mathrm{KMnO}_{4}$ is monolayer adsorption and that the Ox- FVESP adsorption sites are homogeneous.

250 Same outputs for $\mathrm{KMnO}_{4}$ adsorption as recorded by a chemical modified powder from leaves of 251 neem [24]. Moreover, the Favorable adsorption was confirmed by values of $\mathrm{R}_{\mathrm{L}}$ which ranged 252 between 0 and 1 [13].

253 Furthermore, high adsorption capacities of 1111.11, 1250.00, and 1428.57 (mg/g) (Table 2) were 254 achieved, at three temperatures that were used in this study. This demonstrates that Ox- FVESP, 255 as a low-cost and very effective adsorbent, will be of particular importance in the purification of 256 wastewaters from the $\mathrm{KMnO}_{4}$.

\section{3.4. Contact time impact and Kinetic studies}

258 To investigate the contact time impact on the $\mathrm{KMnO}_{4}$ adsorption experiment, the contact time (t) 259 has been graphed against $\mathrm{Q}_{\mathrm{t}}(\mathrm{mg} / \mathrm{g})$ (adsorption quantity at such time $\left.\mathrm{t}\right)$ for the adsorption of (50, 260100 , and $200 \mathrm{mg} / \mathrm{L}) \mathrm{KMnO}_{4}$ concentrations by the ideal dose of chemically modified FVESP 261 adsorbent selected for this work (Figure 9). Figure 9 shows that there are three adsorption 262 regions, the region $\mathrm{I}(0-16 \mathrm{~min})$ where the adsorption amount $\left(\mathrm{Q}_{\mathrm{t}}\right)$ rapidly augmented, while the 263 increase in region II (16-64 min) was regularly and after 64 minutes till the end of the experiment 264 time, it was practically consistent (region III). This indicates that the majority of the adsorbent 265 sites were empty at the start of the adsorption process, and with time all the OX- FVESP sites 266 became full of $\mathrm{KMnO}_{4}$ particles. The same results for $\mathrm{KMnO}_{4}$ adsorption were obtained by a 267 powder of sage leaves modified by zinc chloride [23]. It is also noted from the same figure that 268 the equilibrium time occurred at the 45 th minute of the experiment time. 
269 Furthermore, the experimental outcomes of this adsorption have been studied according to 270 Pseudo-first order, pseudo- second order, and Intraparticle diffusion kinetics models figure 10

271 (a), (b), and figure 11. The slopes and intercepts of these plots were used to calculate the kinetic 272 parameters and summarized in table (3) and (4), the linear relationships observed by applying the 273 pseudo- second order model in Figure 10 (b), where the highest $\mathrm{R}^{2}$ values occurred, and the good 274 agreement between the experimental $Q_{e}$ values (table 4) and computed values of $Q_{e}$, which 275 approve that the adsorption of this work followed the second-order kinetic model. And implying 276 that the $\mathrm{MnO}_{4}^{-}$ions have chemically interacted with functional groups on the OX- FVESP 277 surface. Similar findings were stated for $\mathrm{KMnO}_{4}$ adsorption by activated carbon [12], 278 nanoparticles prepared from copper sulfide [22], and powder sage leaves modified by zinc 279 chloride [23].

280 Intra-particle diffusion plots for $\mathrm{KMnO}_{4}$ adsorption by Ox- FVESP figure 10 and $\mathrm{R}^{2}$ values, 281 table 4 display that the relationship between contact time $(\mathrm{t})$ and adsorption amount $\left(\mathrm{Q}_{\mathrm{t}}\right)$ could 282 not be linear at all, but two different areas are observed. Furthermore, all the plots do not cross 283 the original and this approves that the adsorption of $\mathrm{MnO}_{4}^{-}$ions is not affected by the Intra284 particle diffusion step; migration of $\mathrm{MnO}_{4}^{-}$ions via the Ox- FVESP pores will be very simple. 285 This agrees with the SEM results, as it was clear that the Ox- FVESP surface has a lot of 286 asymmetrical pores.

\section{3.5. Thermodynamic experiment}

288 Equation (XI) was applied to evaluate parameters of the thermodynamic $\Delta \mathrm{H}^{\circ}$, and $\Delta \mathrm{S}^{\circ}$ at three 289 different temperatures for solution Initial concentrations 500, 700, 1000, and 1200 (mg/L). Then, 290 the values of $\Delta \mathrm{G}^{\circ}$ were computed according to equation (XII) based on the previously calculated 291 values of $\Delta \mathrm{S}^{\circ}$ and $\Delta \mathrm{H}^{\circ}$ and illustrated in Table 5. The lowering in the randomness and the 
292 endothermic process of permanganate adsorption by Ox- FVESP adsorbent were confirmed by

293 the positive values of each $\Delta \mathrm{S}^{\circ}$ and $\Delta \mathrm{H}^{\circ}$ (table5) [26]. Moreover, the $\Delta \mathrm{H}^{\circ}$ values are higher than

$29420.9 \mathrm{~kJ} / \mathrm{mol}$, ranging from 27.541 to $34.371 \mathrm{~kJ} / \mathrm{mol}$, which indicates the molecules of adsorbate

295 were chemically adsorbed at the adsorbent surface sites, these results are in agreement with the

296 previous kinetic outputs. Negative values of $\Delta \mathrm{G}^{\circ}$ suggest spontaneous adsorption in the range of

297 temperature that is used in this study, similar findings were stated for $\mathrm{KMnO}_{4}$ adsorption by

298 modified Powder of Ocimum basilicum [26] and other adsorbents developed from very low-cost

299 materials $[22,23]$.

\subsection{A comparative study with other adsorbents}

301 Table 6 summarized the adsorption capacities of $\mathrm{KMnO}_{4}$ removal by Ox- FVESP at three 302 temperatures and the capacities of other synthesized low-cost adsorbents. As presented in table 6, 303 Ox- FVESP adsorbent has a higher adsorption capacity than the conventional low-cost 304 adsorbents that were previously employed to remove $\mathrm{KMnO}_{4}$ from aqueous samples. As a result, 305 The low cost of preparing Ox- FVESP and its high performance in adsorption of permanganate 306 from polluted water give this adsorbent a strong opportunity over other adsorbents.

\section{4. Conclusions}

Modification of the Foeniculum vulgare Seeds (FVES) powder was done by each of $\mathrm{ZnCl}_{2}$,

309 oxalic acid, and $\mathrm{CuS}$, all samples have been characterized by different techniques and examined

310 for permanganate $\left(\mathrm{KMnO}_{4}\right)$ adsorption. Among the four modified and unmodified samples the 311 sample modified by oxalic acid (Ox- FVESP) has the highest percentage removal for $\mathrm{KMnO}_{4}$ 312 adsorption $(\% \mathrm{R}=89.36)$, and was nominated as a new adsorbent for $\mathrm{KMnO}_{4}$ adsorption from the 313 synthesized solutions. The surface area, volume, and size of the pore of the Ox- FVESP 
314 adsorbent were determined as $0.6806 \mathrm{~m}^{2} \mathrm{~g}^{-1}, 0.00215 \mathrm{~cm}^{3} \mathrm{~g}^{-1}$, and $522.063 \AA$, respectively, as

$315 \mathrm{pH}_{\mathrm{ZPC}}$ also was stated to be 7.2. The influence of $\mathrm{KMnO}_{4}$ concentration, Ox- FVESP dose, $\mathrm{pH}$ of

316 the solution, adsorption temperature, and adsorption time on the $\mathrm{KMnO}_{4}$ adsorption was

317 inspected, it can be noted from the experimental outcomes the adsorption performance of

$318 \mathrm{KMnO}_{4}$ was positively affected by the rising concentration of $\mathrm{KMnO}_{4}$ from 10 to $1400 \mathrm{mg} / \mathrm{L}$,

319 Ox- FVESP dose from 0.005 to $0.020 \mathrm{~g}$, contact temperature from $27-57^{\circ} \mathrm{C}$, and adsorption time

320 from 0 to $64 \mathrm{~min}$. while the increase of solution $\mathrm{pH}$ from 1.5 to 11.5 has a negative effect on the

321 adsorption process. The calculated $\mathrm{R}^{2}$ values of different isotherm and kinetic models $(0.999$ and

322 0.996) revealed the adsorption performance of $\mathrm{KMnO}_{4}$ following the Langmuir and Pseudo $2^{\text {nd }}$

323 order models. Constants of thermodynamic $\Delta \mathrm{G}^{\circ}, \Delta \mathrm{H}^{\circ}$, and $\Delta \mathrm{S}^{\circ}$ values indicate chemical and

324 spontaneous adsorption at the adsorbent surface. Additionally, high adsorption capacities were

325 accomplished at three temperatures that were used in this work 1111.11, 1250.00, and 1428.57

$326(\mathrm{mg} / \mathrm{g})$. This will draw attention to use Ox- FVESP adsorbent prepared from very low-cost

327 material to purify water from permanganate.

328 Availability of data and materials

329 All data generated or analyzed during this study are available with the authors.

330 Competing interests

331 The authors declare they have no competing interests.

332 Authors' contributions

333 Methodology, Validation, Conceptualization Formal analysis, Investigation, Writing - Original 334 Draft, Writing - Reviewing \& Editing.

\section{$335 \quad$ Funding}

336 This work has not been funded by any party. 


\section{Acknowledgments}

338 The authors are appreciative to the University of Tabuk's Faculty of Science for their assistance 339 and facilities in completing this work.

340

341

342

343

344

345

346

347

348

349

350

351

352

353

354

355

356

357

358

359 


\section{References}

1. Verma RK, Kapoor R, Gupta SK, Chaudhari RR. An efficient technique for removal of $\mathrm{K}^{+}$ and $\mathrm{MnO}_{4}{ }^{-}$ions through adsorption in aqueous solution by using activated charcoal. Pharm Chem J 2014;1: 20-5.

2. Elsheikh M, Guirguis H, Fathy A. Removal of iron and manganese from groundwater: a study of using potassium permanganate and sedimentation. In MATEC Web of Conferences 2018;162 (EDP Sciences):05018.

3. Ahmad A, Cornelissen E, van de Wetering S, van Dijk T, van Genuchten C, Bundschuh J, et al. Arsenite removal in groundwater treatment plants by sequential Permanganate-Ferric treatment. J Water Process. Eng 2018;26: 221-9.

4. Rodríguez E, Onstad GD, Kull TP, Metcalf JS, Acero JL, von Gunten U. Oxidative elimination of cyanotoxins: comparison of ozone, chlorine, chlorine dioxide, and permanganate. Water Res 2007;41: 3381-93.

5. He D, Guan X, Ma J, Yang X, Cui C. Influence of humic acids of different origins on oxidation of phenol and chlorophenols by permanganate. J Hazard Mater 2010;182:681-8.

6. Liu C, Zhang L, Li F, Wang Y, Gao Y, Li X, et al. Dependence of sulfadiazine oxidative degradation on physicochemical properties of manganese dioxides. Ind Eng Chem Res 2009; 48:10408-13.

7. Jiang J, Pang SY, Ma J. Oxidation of triclosan by permanganate (Mn (VII)): importance of ligands and in situ formed manganese oxides. Environ Sci Technol. 2009;43:8326-31.

8. Kao CM, Huang KD, Wang JY, Chen TY, Chien HY. Application of potassium permanganate as an oxidant forin situ oxidation of trichloroethylene-contaminated groundwater: a laboratory and kinetics study. J Hazard Mater 2008;153:919-27.

9. Hazardous Substance Fact Sheet, Potassium Permanganate, New Jersy Department of Health and Senior Services, March 1986, Revised May 2002, 2-6.

10. Abdeen Z, Mohammad SG, Mahmoud MS. Adsorption of Mn (II) ion on polyvinyl alcohol/chitosan dry blending from aqueous solution Environ. Nanotechnol Monit 2015;3:1-9.

11. Li GX, Huaug YH, Chen TC, Shih YJ, Zhang H. Reduction and immobilization of potassium permanganate on iron oxide catalyst by fluidized-bed crystallization technology. Appl Sci 2012;2:166-174.

12. Aprilliani F, Warsiki E, Iskandar A. Kinetic studies of potassium permanganate adsorption by activated carbon and its ability as ethylene oxidation material. InIOP Conf. Series: Environ Earth Sci 2018;141012003.

13. Ezeugo DJ, Anadebe CV. Removal of potassium permanganate from aqueous solution by adsorption onto activated carbon prepared from animal bone and corn cob Equatorial J Eng 2018;2018:14-21.

14. Mahmoud ME, Yakout AA, Saad SR, Osman MM. Removal of potassium permanganate from water by modified carbonaceous materials. Desalination Water Treat 2016;57:15559-69. 
15. Li F, Wu X, Ma S, Xu Z, Liu W, Liu F. Adsorption and desorption mechanisms of methylene blue removal with iron-oxide coated porous ceramic filter. JWARP 2009;1:1-57.

16. Rani S, Aggarwal M, Kumar M, Sharma S, Kumar D. Removal of methylene blue and rhodamine B from water byzirconium oxide/grapheme. Water Sci 2016;30:51-60.

17. Tavakkoli H, Hamedi F. Synthesis of $\mathrm{Gd} 0.5 \mathrm{Sr} 0.5 \mathrm{FeO} 3$ perovskite-type nano-powders for adsorptive removal of MB dye from water. Res Chem Intermed 2016;42:3005-27.

18. Chin LY, Pei LY, Rosli RB, MohdAtni NHB. Immobilization of nano-sized TiO2 on glass plate for the removal of methyl orange and methylene blue. ICGSCE. 2015;2014: (Singapore: Springer)105-13.

19. Yang ST, Chen S, Chang Y, Cao A, Liu Y, Wang H. Removal of methylene blue from aqueous solution by graphene oxide. J. Colloid Interface Sci 2011;359:24-9.

20. Mustafa G, Tahir H, Sultan M, Akhtar N. Synthesis and characterization of cupric oxide $(\mathrm{CuO})$ nanoparticles and their application for the removal of dyes. Afr $\mathrm{J}$ Biotechnol 2013;12:6650-60.

21. Al-Aoh HA, Mihaina IA, Alsharif MA, Darwish AAA, Rashad M, Mustafa SK, et al. Removal of methylene blue from synthetic wastewater by the selected metallic oxides nanoparticles adsorbent: equilibrium, kinetic and thermodynamic studies. Chem Eng Commun 2019;1-17.

22. Aljohani MMH, Al-Aoh HA. Adsorptive removal of permanganate anions from synthetic wastewater using copper sulfide nanoparticles. Mater Res Express 2021;8:035012.

23. Bani-Atta SA. Zinc chloride modification of sage leaves powder and its application as an adsorbent for $\mathrm{KMnO}_{4}$ removal from aqueous solutions. Mater Res Express 2020; 7: 095511.

24. Al-Aoh HA. Equilibrium, thermodynamic and kinetic study for potassium permanganate adsorption by neem leaves powder. Desalination Water Treat. 2019;170:101-10.

25. Al-Aoh HA. Adsorption of $\mathrm{MnO}_{4}{ }^{-}$from aqueous solution by Nitraria retusa leaves powder; kinetic, equilibrium and thermodynamic studies. Mater Res Express 2019;6:115102.

26. Alamrani NA, Al-Aoh HA, Aljohani MH, Bani-Atta SA, Sobhi M, Mustafa SK, et al. Wastewater Purification from Permanganate Ions by Sorption on the Ocimum basilicum Leaves Powder Modified by Zinc Chloride. J Chem 2021;1-10.

27. Badgujar SB, Patel VV, Bandivdekar AH. Foeniculum vulgare Mill: a review of its botany, phytochemistry, pharmacology, contemporary application, and toxicology. Biomed Res Int 2014;1-33.

28. Purkayastha S, Narain R, Dahiya P. Evaluation of antimicrobial and phytochemical screening of Fennel, Juniper and Kalonji essential oils against multi drug resistant clinical isolates. Asian Pac J Trop Biomed 2012;2:S1625-S1629.

29. Roby MHH, Sarhan MA, K. Selim AH, Khalel KI. Antioxidant and antimicrobial activities of essential oil and extracts of fennel (Foeniculum vulgare L.) and chamomile (Matricaria chamomilla L.) Ind Crops Prod 2013;44:437-445. 
442 443

444 445

59

61

62

30. Choudhary MK, Kataria J, Sharma S. A biomimetic synthesis of stable gold nanoparticles derived from aqueous extract of Foeniculum vulgare seeds and evaluation of their catalytic activity. Appl Nanosci 2017;7:439-447.

31. Sudirman Y, Apriandanu DOB, Al Jabbar JL. Facile one-pot preparation of $\mathrm{V}_{2} \mathrm{O}_{5}-\mathrm{Fe}_{2} \mathrm{O}_{3}$ nanocomposites using Foeniculum vulgare extracts and their catalytic property. Inorg Chem Commun 2021;123:108320.

32. Qu B, Zhou J, Xiang X, Zheng C, Zhao H, Zhou X. Adsorption behavior of Azo Dye C.I. Acid Red 14inaqueous solution on surface soils. J Environ Sci 2008;20: 704-709.

33. Kuchekar SR, Patil PM, Vishwas B, Gaikwad H, Han S. Synthesis and characterization of silver nanoparticles using Azadirachta indica (Neem) leaf extract. Int j eng 2017;6:47-55.

34. Nekouei F, Nekouei S, Tyagi I, Gupta VK. Kinetic, thermodynamic and isotherm studies for acid blue 129 removal from liquids using copper oxide nanoparticlemodified activated carbon as a novel adsorbent. J Mol Liq 2015; 201: 124-133.

35. Alamrani AN, Al-Aoh HA. Elimination of Congo Red Dye from Industrial Wastewater Using Teucrium polium L. as a Low-Cost Local Adsorbent. Adsorp Sci Technol 2021;2021:112.

3

(1)

5

.

7

8

60

\section{Figure caption}

\begin{tabular}{|l|l|}
\hline Figure 1: & Spectra of FT-IR for the FVESP, Ox- FVESP, Zn- FVESP, and Zn/Cu- FVESP. \\
\hline
\end{tabular}




\begin{tabular}{|c|c|}
\hline Figure 2: & $\begin{array}{l}\text { SEM images of a) FVESP, b) Zn- FVESP, c) Ox- FVESP, and d) Zn/Cu- } \\
\text { FVESP. }\end{array}$ \\
\hline Figure 3: & $\mathrm{pH}_{\mathrm{ZPC}}$ of the Ox- FVESP adsorbent. \\
\hline Figure 4: & The percentage removal for $\mathrm{KMnO}_{4}$ adsorption by four different samples. \\
\hline Figure 5: & The $\mathrm{pH}$ solution impact on the of $\mathrm{KMnO}_{4}$ adsorption by Ox- FVESP adsorbent. \\
\hline Figure 6: & Effect of dose on adsorption performance of Ox- FVESP for $\mathrm{KMnO}_{4}$ \\
\hline Figure 7: & $\begin{array}{l}\text { Impacts of initial concentration and temperature on the } \mathrm{KMnO}_{4} \text { adsorption by } \\
\text { Ox- FVESP }\left(\mathrm{C}_{0}=10-1400 \mathrm{mg} / \mathrm{L}, \mathrm{m}=0.02 \mathrm{~g} \text {, time }=26 \mathrm{~h} \text {, and three temperatures }\right. \\
\left.27,42.57^{\circ} \mathrm{C}\right) .\end{array}$ \\
\hline Figure 8: & $\begin{array}{l}\text { a) Langmuir, b) Freundlich, and c) Temkin isotherm models for adsorption of } \\
\mathrm{KMnO}_{4} \text { by Ox- FVESP, (temperature }=27,42.57^{\circ} \mathrm{C}, \mathrm{C}_{0}=10-1400 \mathrm{mg} / \mathrm{L}, \mathrm{m}= \\
0.02 \mathrm{~g} \text {, and time }=22 \mathrm{~h} \text { ). }\end{array}$ \\
\hline Figure 9: & $\begin{array}{l}\text { Impact of adsorption time on } \mathrm{KMnO}_{4} \text { adsorption by Ox- FVESP (temperature }= \\
\left.27^{\circ} \mathrm{C}, \mathrm{C}_{0}=50,100,200 \mathrm{mg} / \mathrm{L}, \mathrm{m}=0.02 \mathrm{~g} \text {, and time }=0-320 \mathrm{~min}\right) .\end{array}$ \\
\hline Figure 10: & $\begin{array}{l}\text { a) Kinetic model of the } 1^{\text {st }} \text { order, b) Kinetic model of the } 2^{\text {nd }} \text { order for } \mathrm{KMnO}_{4} \\
\text { adsorption by Ox- FVESP (temperature }=27^{\circ} \mathrm{C}, \mathrm{C}_{0}=50,100,200 \mathrm{mg} \cdot \mathrm{L}^{-1}, \mathrm{~m}= \\
0.02 \mathrm{~g} \text {, and time }=0-320 \mathrm{~min}) .\end{array}$ \\
\hline Figure 11: & $\begin{array}{l}\text { Model of intra-particle diffusion for } \mathrm{KMnO}_{4} \text { adsorption by Ox- FVESP } \\
\text { (temperature }=27^{\circ} \mathrm{C}, \mathrm{C}_{0}=50,100,200 \mathrm{mg} . \mathrm{L}^{-1}, \mathrm{~m}=0.02 \mathrm{~g} \text {, and time }=0-320 \\
\text { min). }\end{array}$ \\
\hline
\end{tabular}




\begin{tabular}{|l|l|}
\hline Table 1: & BET surface analyzer of FVESP, Ox- FVESP, $\mathrm{Zn}$ - FVESP, and $\mathrm{Zn} / \mathrm{Cu}-\mathrm{FVESP}$. \\
\hline Table 2: & $\begin{array}{l}\text { Isotherm constants of Langmuir, Freundlich, and Temkin models for } \mathrm{KMnO}_{4} \\
\text { adsorption by Ox- FVESP. }\end{array}$ \\
\hline Table 3: & $\begin{array}{l}\text { Parameters of the } 1^{\text {st }} \text { and } 2^{\text {nd }} \text {-order kinetic models for adsorption of } \mathrm{KMnO}_{4} \text { by Ox- } \\
\text { FVESP. }\end{array}$ \\
\hline Table 4: & $\begin{array}{l}\text { Parameters of the intra-particle- diffusion kinetic model for } \mathrm{KMnO}_{4} \text { adsorption by } \\
\text { Ox- FVESP. }\end{array}$ \\
\hline Table 5: & Thermodynamic constants for $\mathrm{KMnO}_{4}$ adsorption by Ox- FVESP. \\
\hline Table 6: & Adsorption capacities for $\mathrm{KMnO}_{4}$ removal by several adsorbents. \\
\hline
\end{tabular}

472

473

474

475

476

477

478

479

480

481

482

483

484

485

486

487 
$488 \quad$ Fig. 1

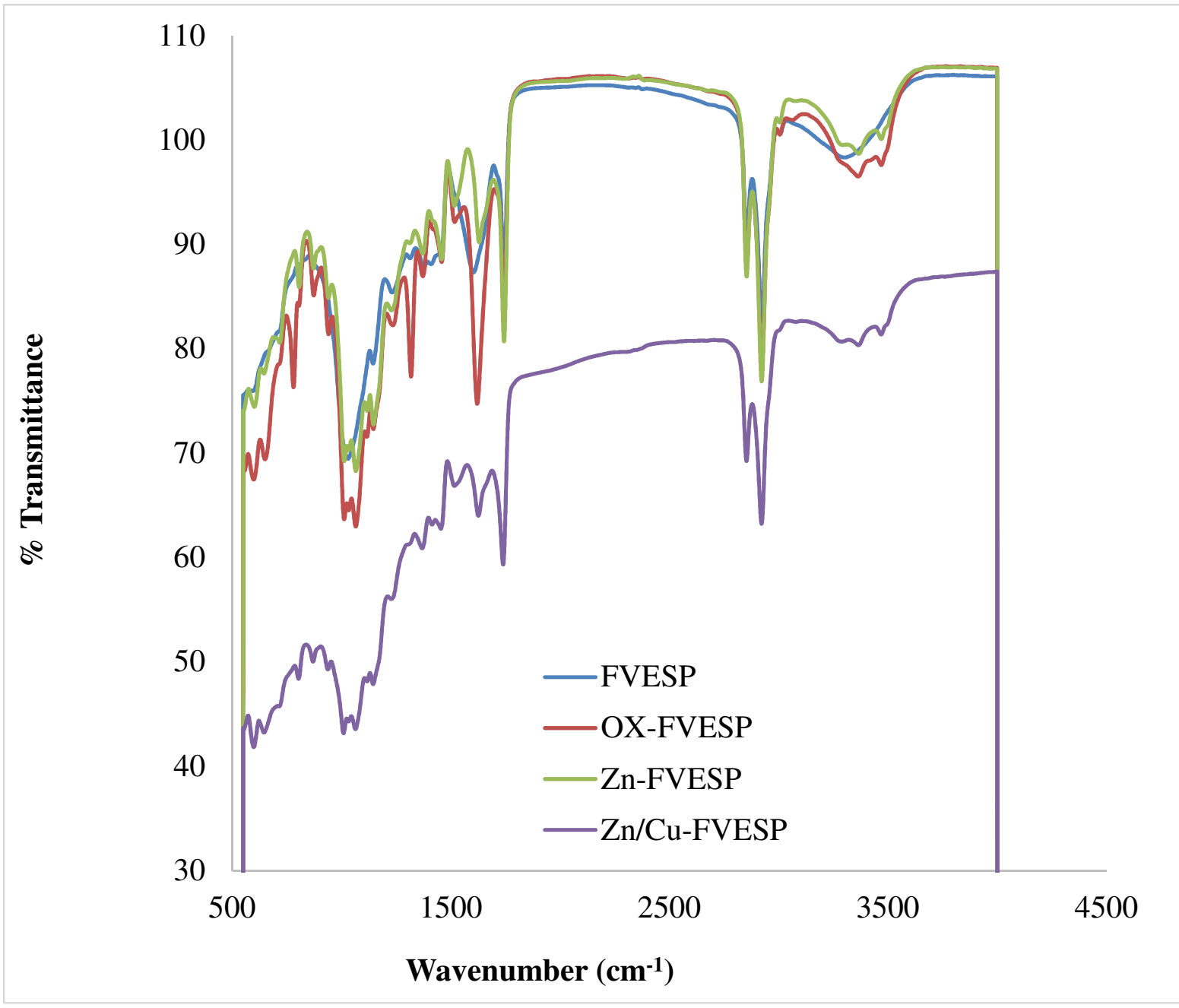

490

491

492

493

494

495

496

497 
Fig. 2

499

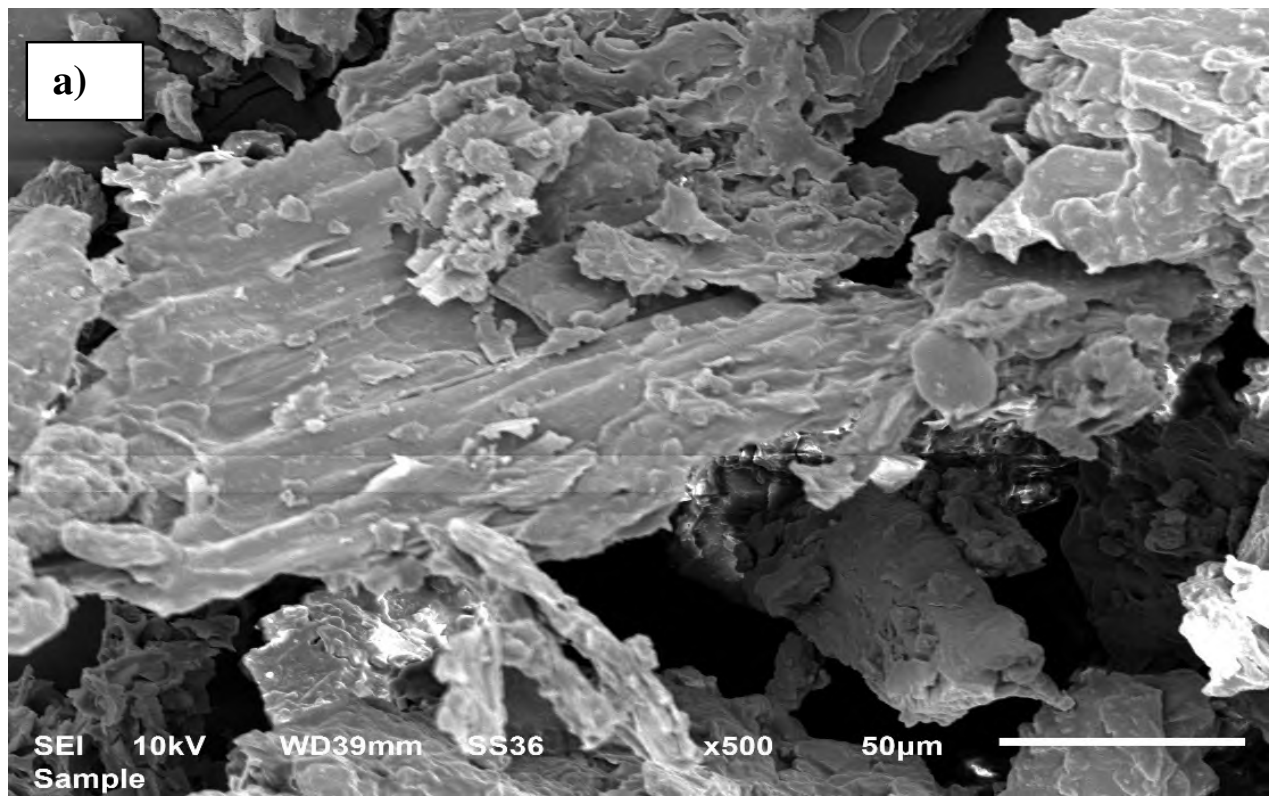

500

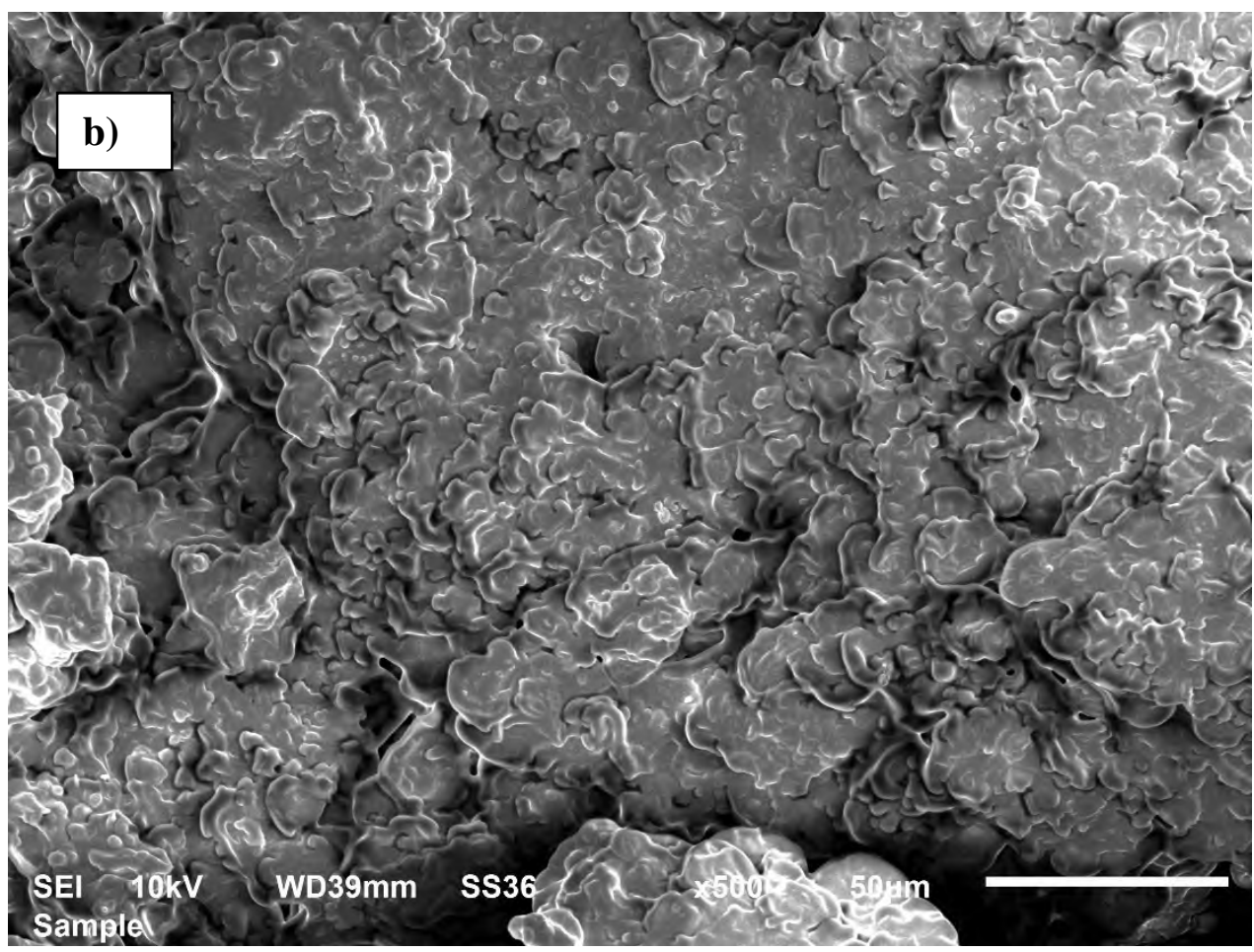




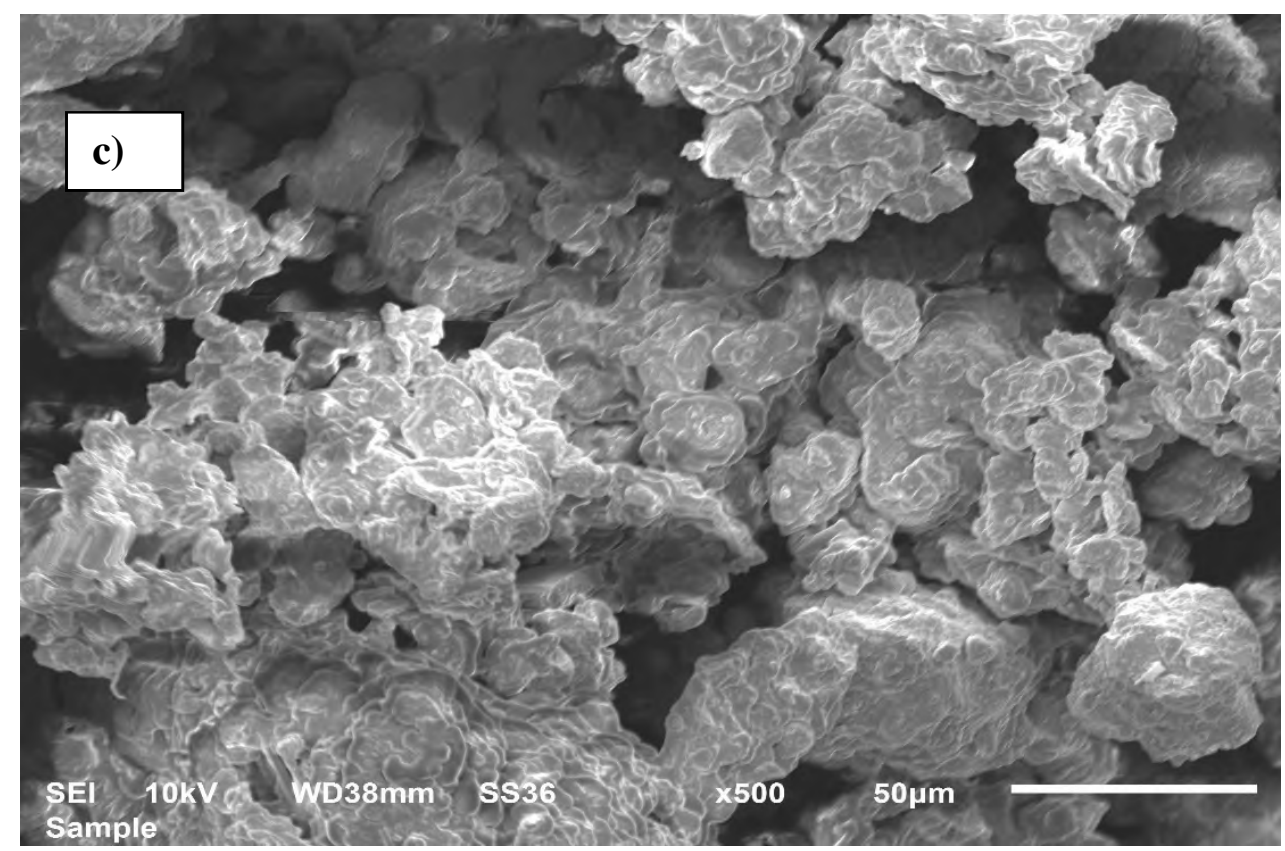

503

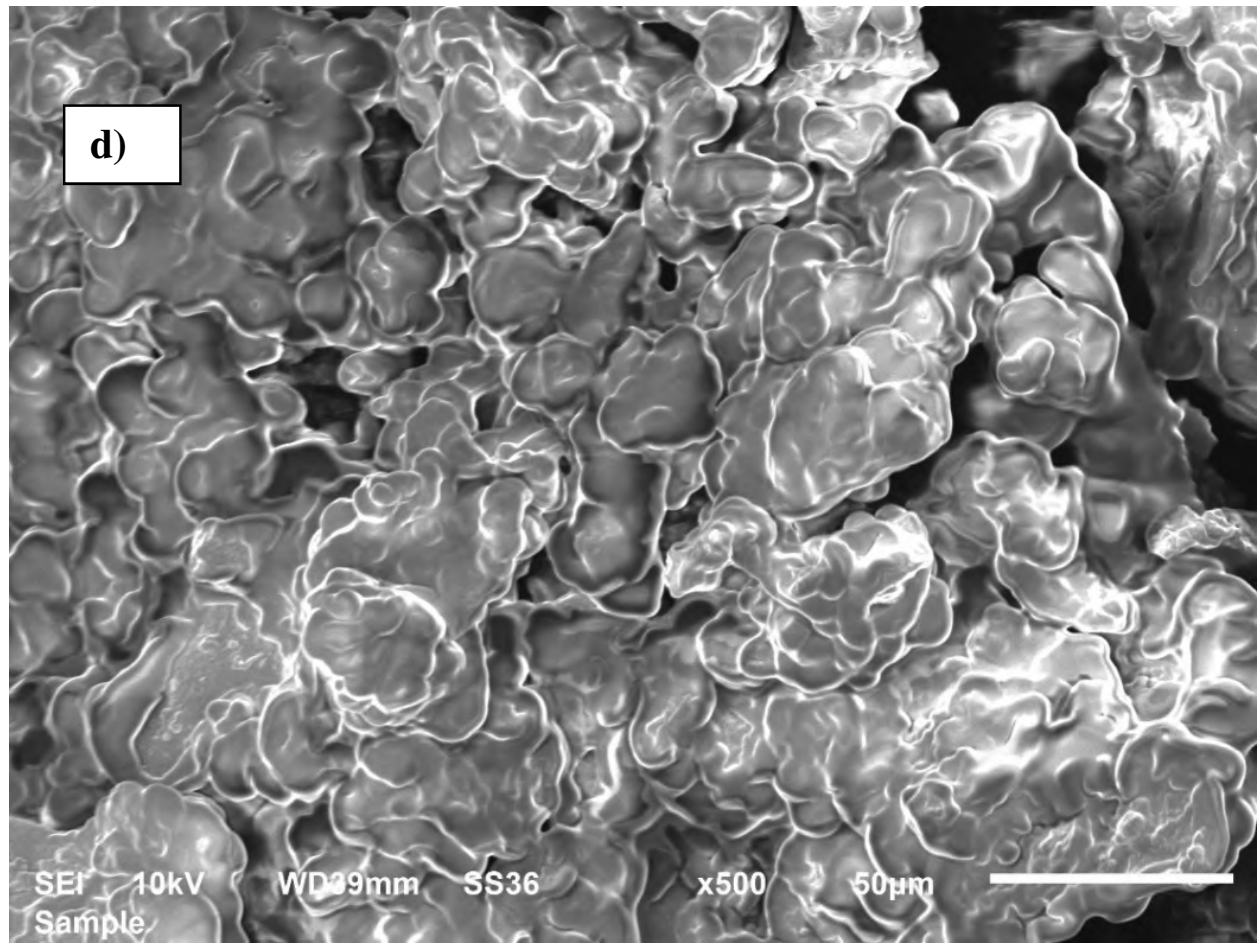

505

506

507 
$509 \quad$ Fig. 3

510

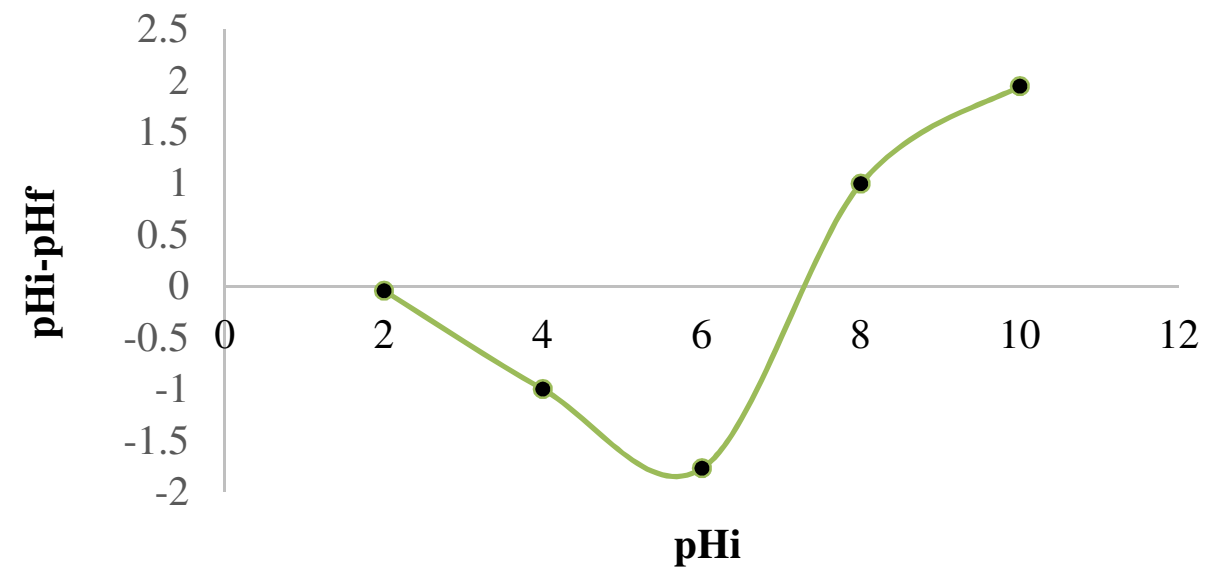

512

513

514

515

516

517

518

519

520

521

522

523

524

525 
$527 \quad$ Fig. 4

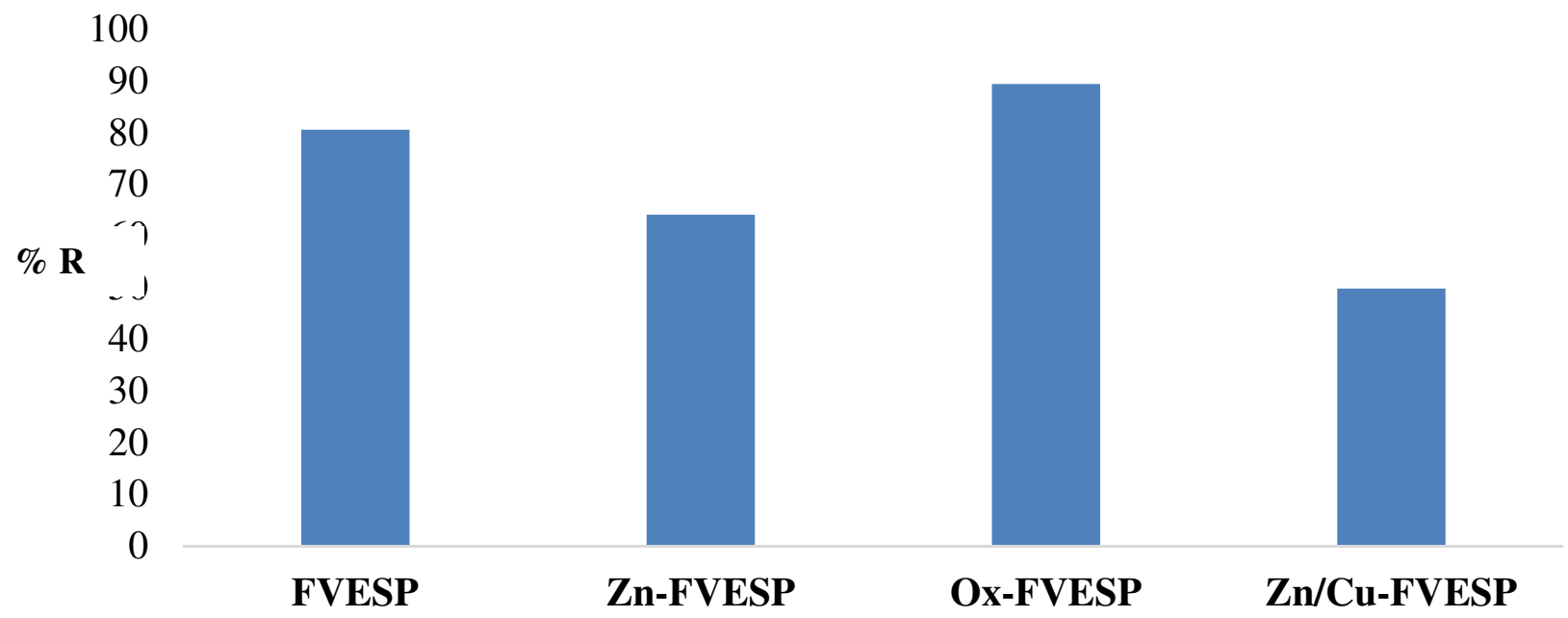

528

529

530

531

532

533

534

535

536

537

538

539

540

541

542

543

544

545

546

547

548

549

550

551

552

553

554 
$555 \quad$ Fig. 5

556

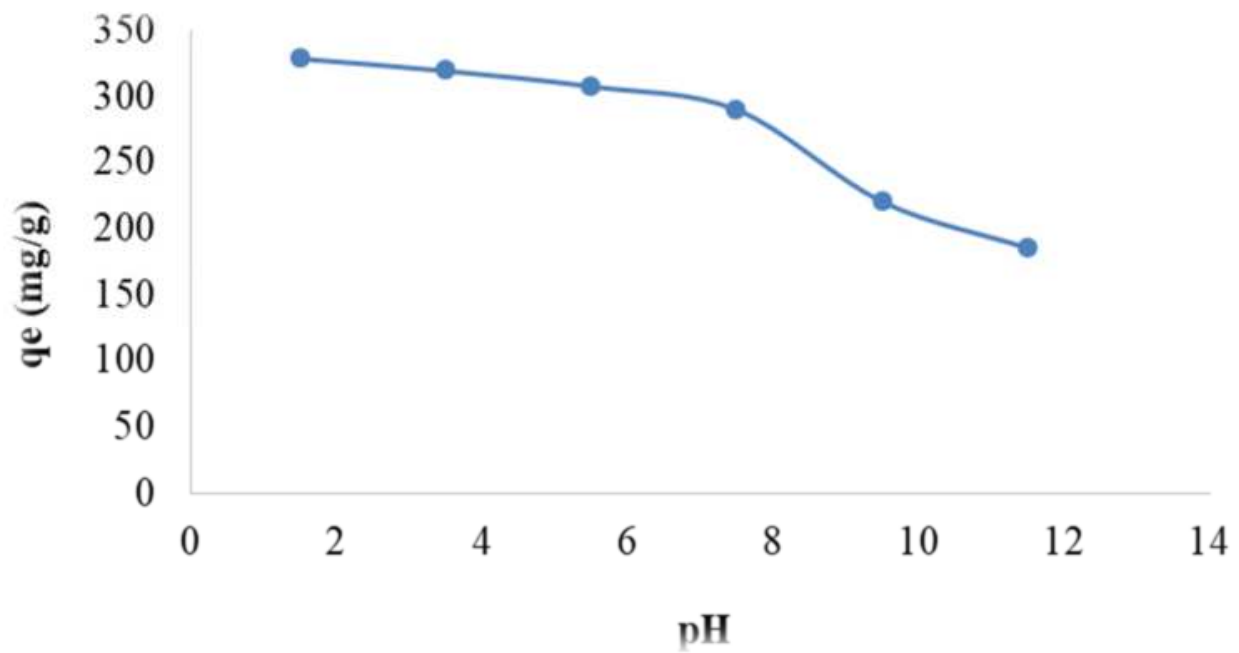

557

558

559

560

561

562

563

564

565

566

567

568

569

570

571

572

573

574

575

576

577 
578

$579 \quad$ Fig. 6

580

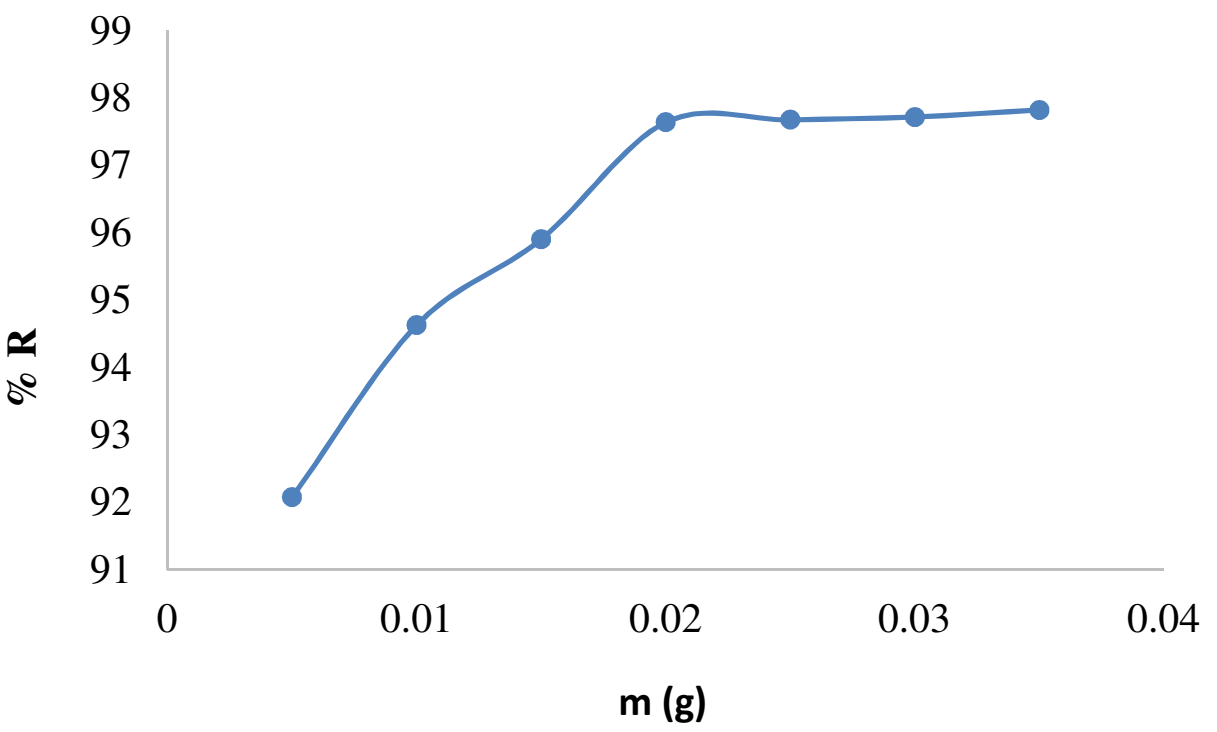

581

582

583

584

585

586

587

588

589

590

591

592

593

594

595

596

597 
Fig. 7

599

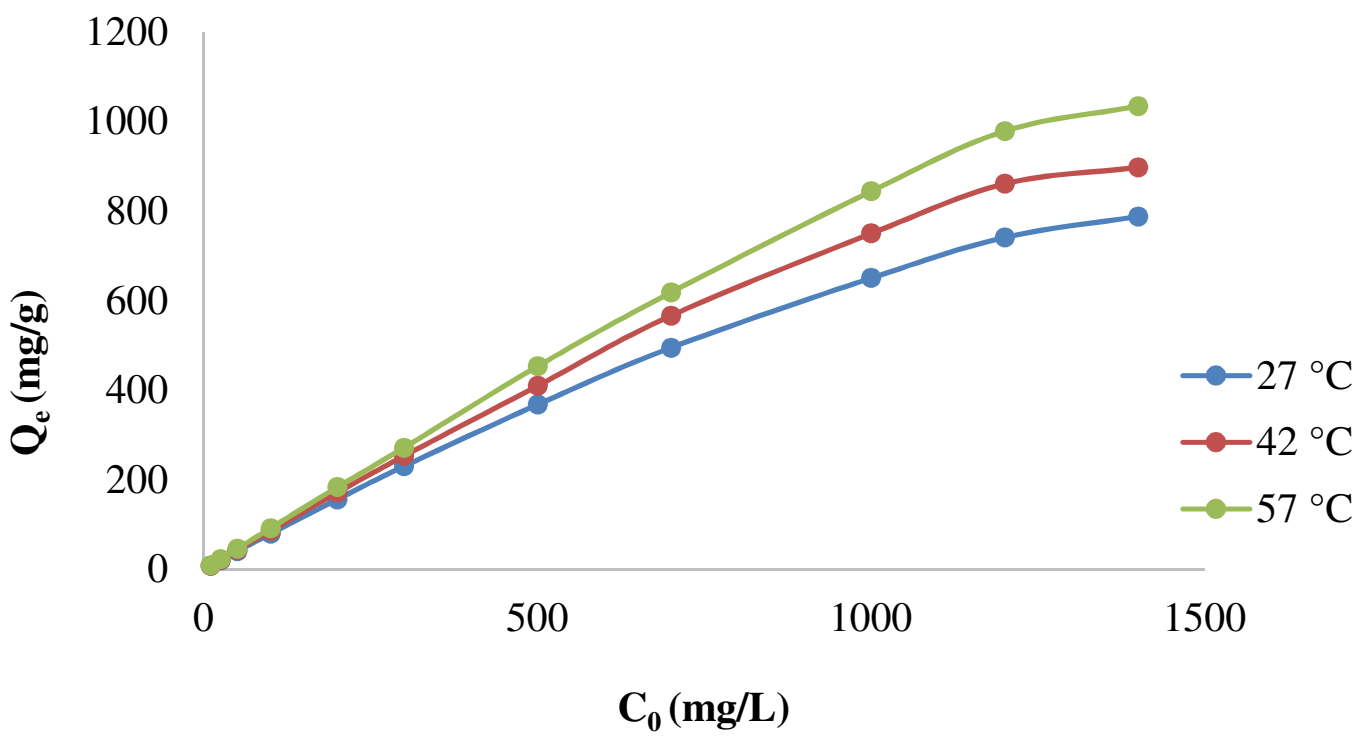

601

602

603

604

605

606

607

608

609

610

611

612

613

614

615

616 
$617 \quad$ Fig. 8

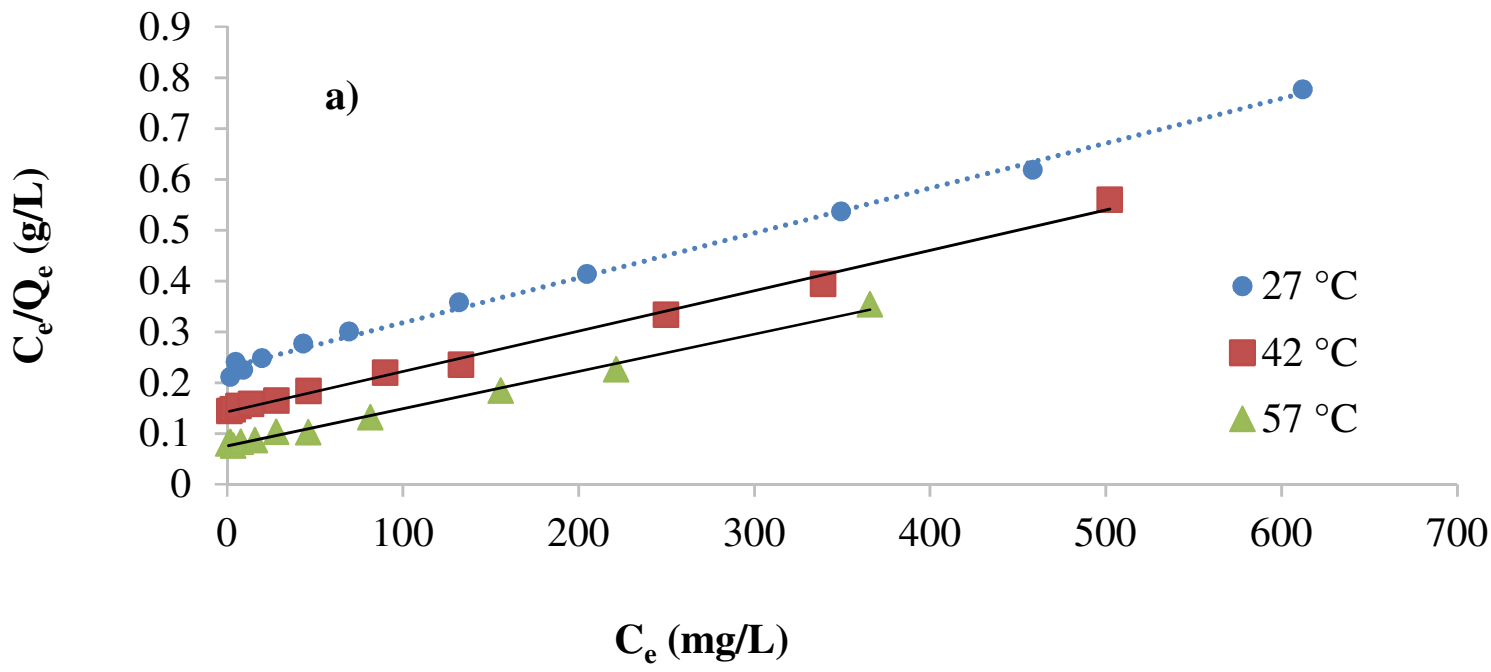

619

620

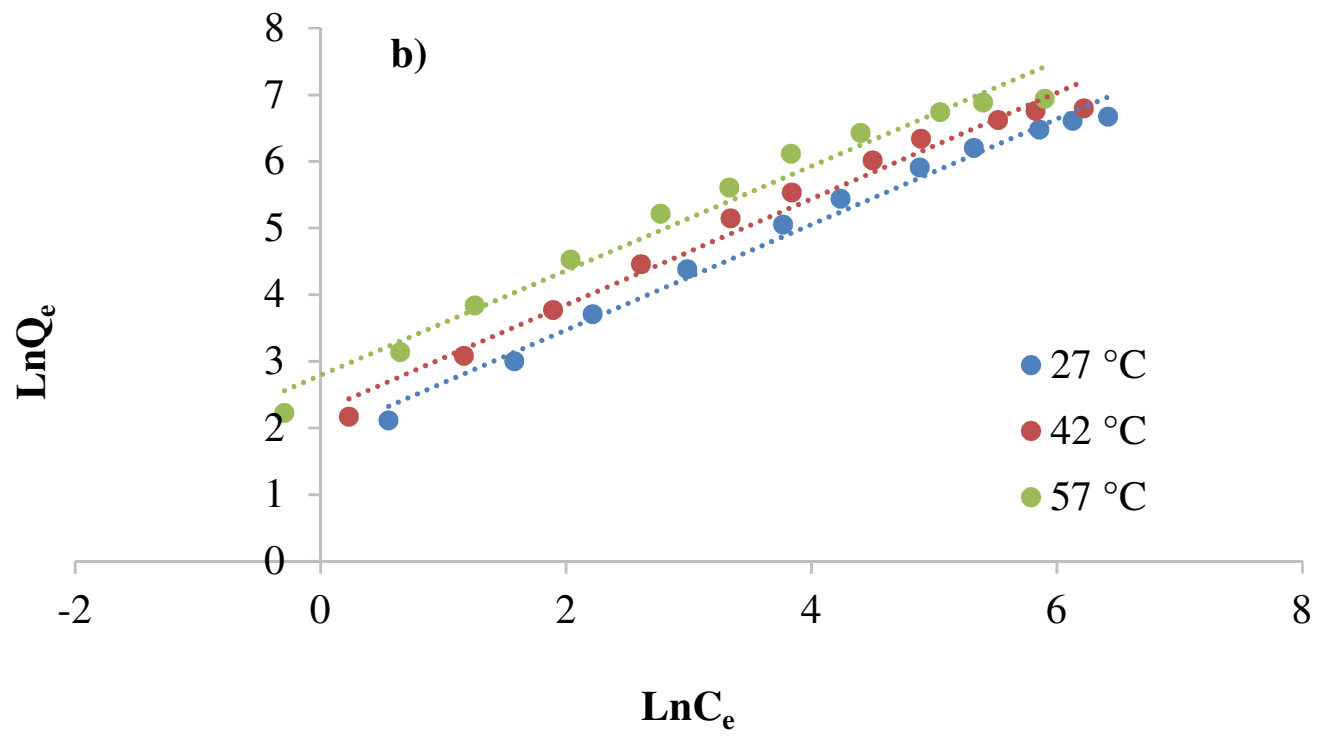

621 


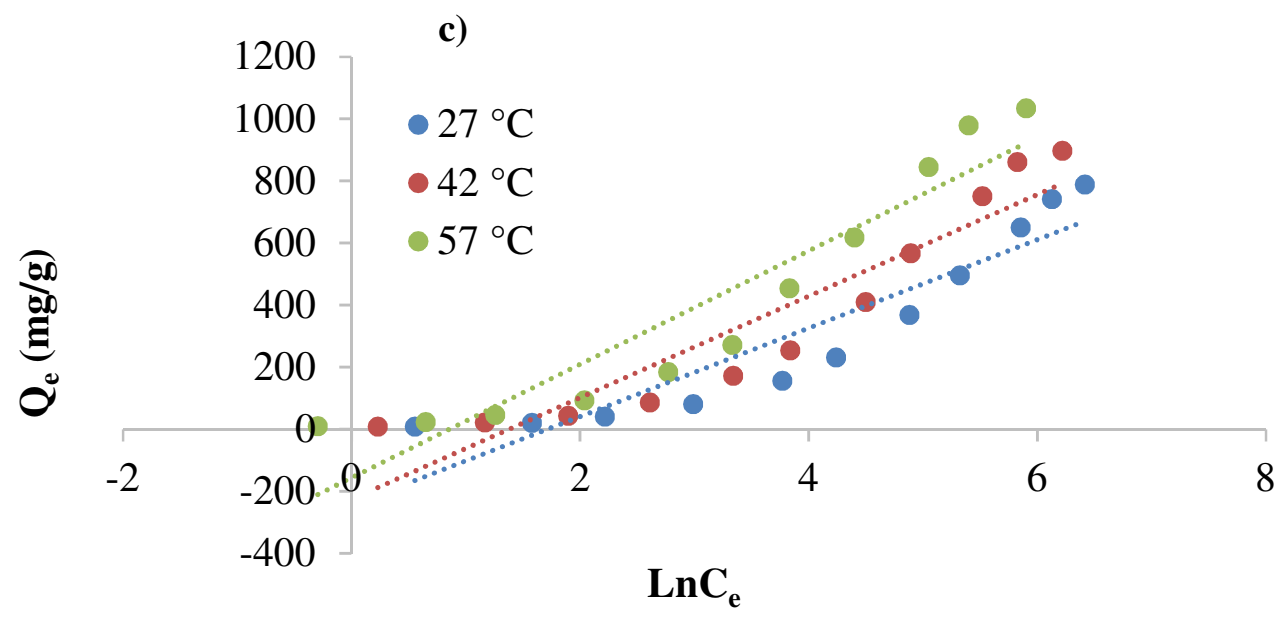

622

623

624

625

626

627

628

629

630

631

632

633

634

635

636

637

638

639

640

641 
642 Fig. 9

643

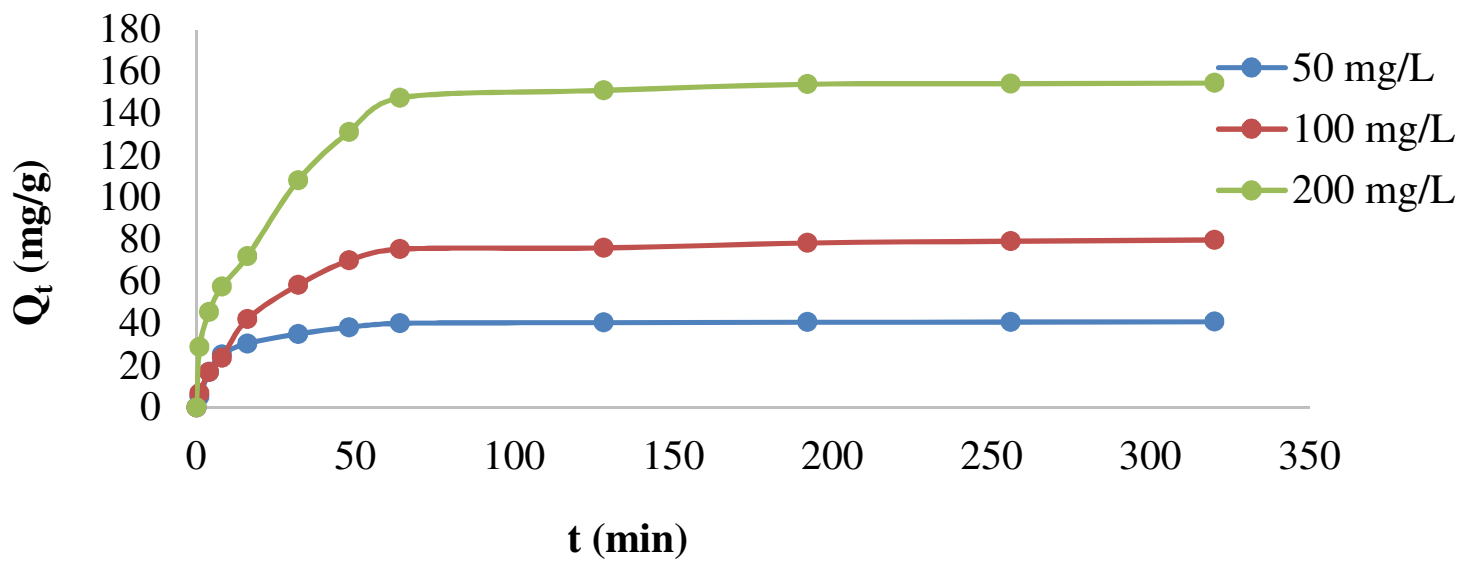

644

645

646

647

648

649

650

651

652

653

654

655

656

657

658

659

660

661 
662

Fig. 10

663

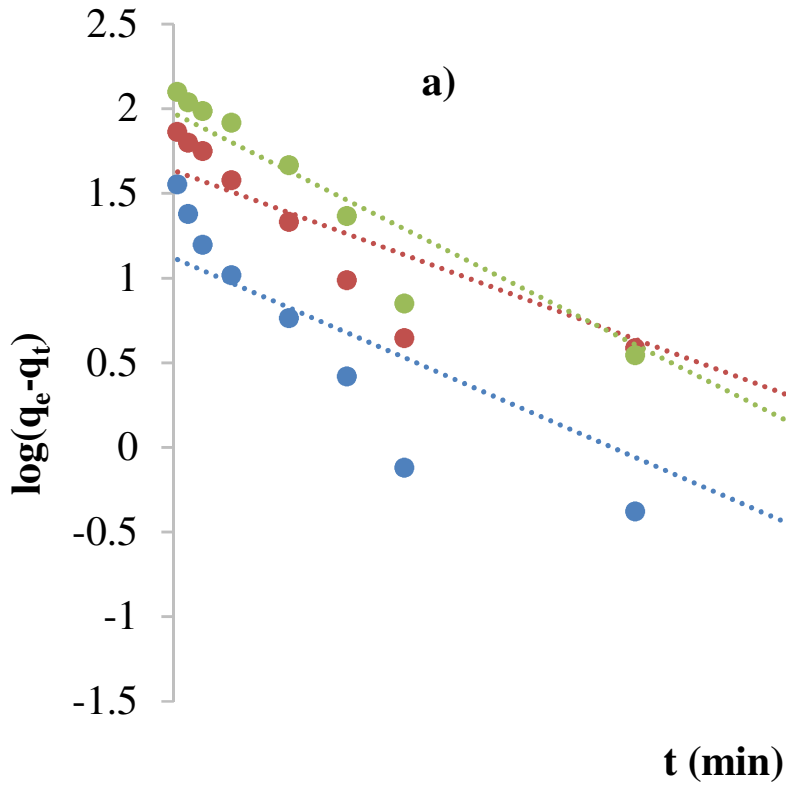

664

665

666

667

668

669

670

671

b)

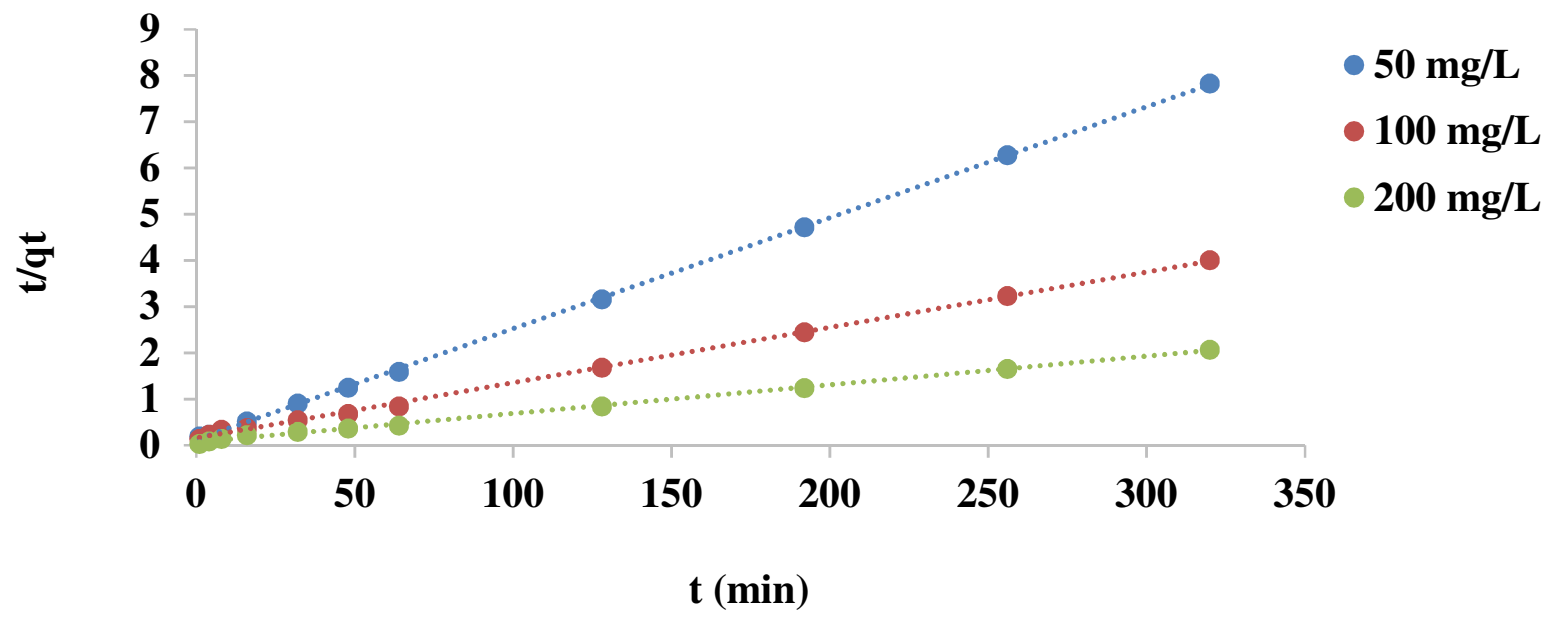


$672 \quad$ Fig. 11

673

674

675

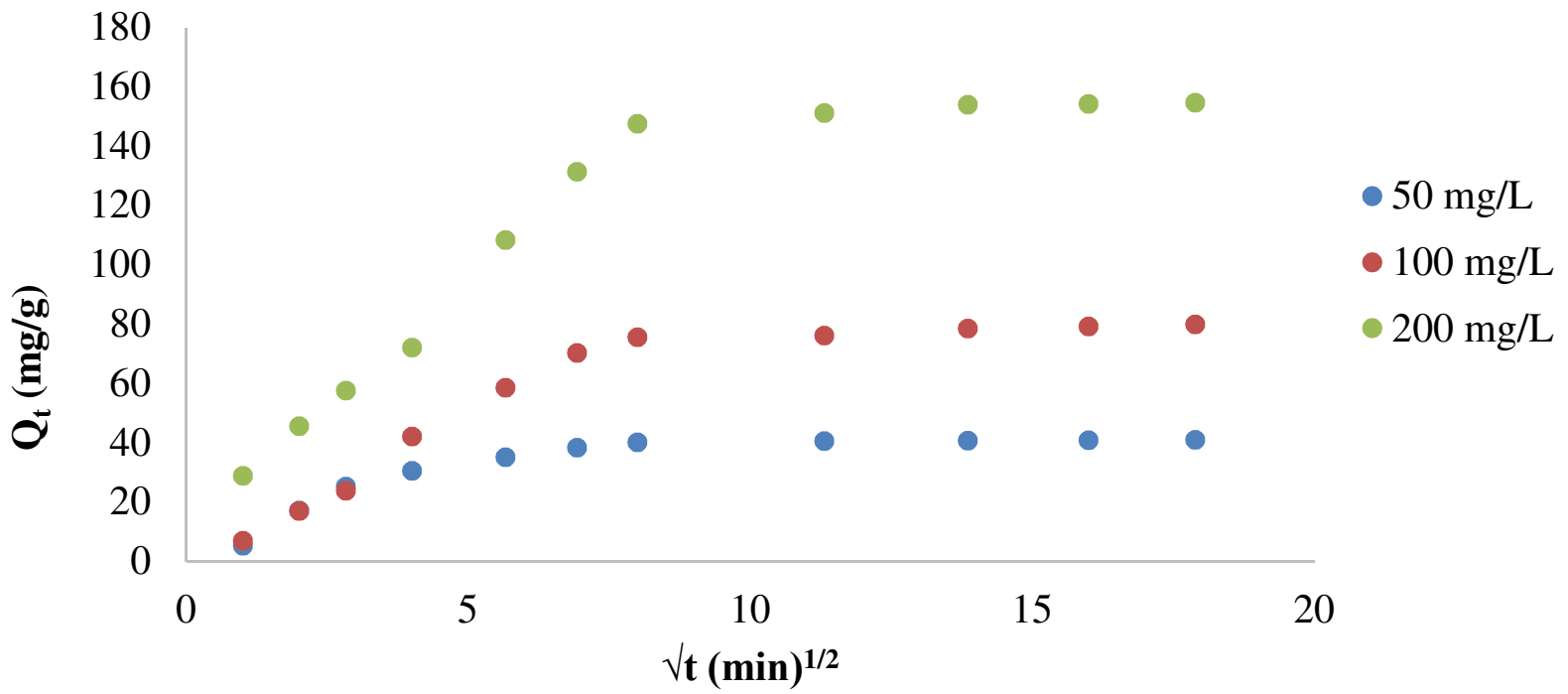

676

677

678

679

680

681

682

683

684

685

686

687

688

689

690 
Table 1

\begin{tabular}{cccc}
\hline Sample & Surface Area $\left(\mathbf{m}^{2} \cdot \mathbf{g}^{-1}\right)$ & Volume of Pore $\left(\mathbf{c m}^{3} \cdot \mathbf{g}^{-1}\right)$ & $\begin{array}{c}\text { Size of Pore } \\
(\AA)\end{array}$ \\
FVESP & 0.0249 & 0.00153 & 53.001 \\
Ox- FVESP & 0.6806 & 0.00215 & 522.063 \\
Zn- FVESP & 0.3087 & 0.00214 & 91.717 \\
$\mathrm{Zn} / \mathrm{Cu}-\mathrm{FVESP}$ & 0.3979 & 0.00061 & 91.037 \\
\hline
\end{tabular}

694

695

696

697

698

699

700

701

702

703

704

705

706

707

708

709

710 
712

713 Table 2

714

\begin{tabular}{|c|c|c|c|c|c|c|c|c|c|c|c|}
\hline \multirow{3}{*}{ Temperature } & \multicolumn{11}{|c|}{ Isotherm parameters } \\
\hline & \multicolumn{4}{|c|}{ Langmuir } & \multicolumn{4}{|c|}{ Freundlich } & \multicolumn{3}{|c|}{ Temkin } \\
\hline & $\underset{\left(\mathrm{mg} \cdot \mathrm{g}^{-1}\right)}{\mathrm{q}_{\max }}$ & $\begin{array}{c}\mathrm{K}_{\mathrm{L}} \\
\left(\mathrm{L} . \mathrm{mg}^{-1}\right)\end{array}$ & $\mathrm{R}_{\mathrm{L}}$ & $\mathrm{R}^{2}$ & $\begin{array}{c}\mathrm{KF}_{\mathrm{F}} \\
\left(\mathrm{mg} \cdot \mathrm{g}^{-1}\right)\left(\mathrm{L} \cdot \mathrm{mg}^{-1}\right)^{1 / n}\end{array}$ & $1 / \mathrm{n}$ & $\mathrm{n}$ & $\mathrm{R}^{2}$ & $\begin{array}{c}\mathrm{K}_{\mathrm{T}} \\
\left(\mathrm{L} . \mathrm{mg}^{-1}\right)\end{array}$ & $\mathrm{B}_{1}$ & $\mathrm{R}^{2}$ \\
\hline $27^{\circ} \mathrm{C}$ & 1111.11 & 0.00392 & 0.15408 & 0.996 & 6.2557 & 0.792 & 1.2625 & 0.988 & 0.18027 & 142.58 & 0.871 \\
\hline $42{ }^{\circ} \mathrm{C}$ & 1250.00 & 0.00561 & 0.11294 & 0.994 & 9.5735 & 0.796 & 1.2560 & 0.982 & 0.25209 & 163.59 & 0.878 \\
\hline $57^{\circ} \mathrm{C}$ & 1428.57 & 0.00928 & 0.07144 & 0.994 & 13.6154 & 0.785 & 1.2740 & 0.975 & 0.42520 & 182.81 & 0.886 \\
\hline
\end{tabular}

715

716

717

718

719

720

721

722

723

724

725

726

727

728

729

730

731

732

733

734 
Table 3

\begin{tabular}{|c|c|c|c|c|c|c|c|c|}
\hline \multirow[b]{3}{*}{$\begin{array}{c}\mathrm{C}_{0} \\
\left(\mathrm{mg} \cdot \mathrm{L}^{-1}\right)\end{array}$} & \multirow[b]{3}{*}{$\begin{array}{l}\mathrm{Q}_{\mathrm{e}, \exp } \\
\left(\mathrm{mg} \cdot \mathrm{g}^{-1}\right)\end{array}$} & \multicolumn{7}{|c|}{ Kinetic model } \\
\hline & & \multicolumn{3}{|c|}{$\mathbf{1}^{\text {st }}$ order } & \multicolumn{4}{|c|}{$2^{\text {nd }}$ order } \\
\hline & & $\begin{array}{c}\mathrm{Q}_{\mathrm{el}, \mathrm{cal}} \\
\left(\mathrm{mg} \cdot \mathrm{g}^{-1}\right)\end{array}$ & $\begin{array}{c}\mathrm{K}_{1} \\
\left(\mathrm{~h}^{-1}\right)\end{array}$ & $\mathrm{R}^{2}$ & $\begin{array}{c}\mathrm{Q}_{\mathrm{e} 2, \mathrm{cal}} \\
\left(\mathrm{mg} \cdot \mathrm{g}^{-1}\right)\end{array}$ & $\begin{array}{c}\mathrm{K}_{2} \\
\left(\mathrm{~g} \cdot \mathrm{mg}^{-1} \cdot \mathrm{h}^{-1}\right)\end{array}$ & $\mathrm{R}^{2}$ & Rate \\
\hline 50 & 40.89 & 13.14 & 0.0212 & 0.85 & 41.67 & 0.0046 & 0.999 & 0.19308 \\
\hline 100 & 79.87 & 43.14 & 0.0180 & 0.898 & 83.33 & 0.0009 & 0.999 & 0.07481 \\
\hline 200 & 154.57 & 93.86 & 0.0246 & 0.958 & 161.29 & 0.0005 & 0.998 & 0.08832 \\
\hline
\end{tabular}

738

739

740

741

742

743

744

745

746

747

748

747

\begin{tabular}{lllllll}
\hline \multirow{2}{*}{$\begin{array}{l}C_{o} \\
\left(\mathrm{mg} . \mathrm{L}^{-1}\right)\end{array}$} & \multicolumn{2}{l}{ First region } & $\begin{array}{l}K_{\text {dif }} \\
\left(\mathrm{mg} / \mathrm{h}^{1 / 2} \mathrm{~g}\right)\end{array}$ & $C$ & $R^{2}$ & $\begin{array}{l}\text { Second region } \\
\left(\mathrm{mg} / \mathrm{h}^{1 / 2} \mathrm{~g}\right)\end{array}$ \\
\hline 50 & 5.187 & 5.839 & 0.889 & 0.0743 & 39.59 & $R^{2}$ \\
100 & 10.990 & 9.413 & 0.993 & 0.4868 & 71.27 & 0.973 \\
200 & 17.271 & -4.389 & 0.982 & 0.7332 & 142.44 & 0.900 \\
\hline
\end{tabular}

Table 4

Table 5

\begin{tabular}{|c|c|c|c|c|c|c|}
\hline \multirow{2}{*}{$\begin{array}{c}\text { Initial } \\
\text { concentration } \\
\left(\mathbf{m g . L} \mathbf{L}^{-1}\right)\end{array}$} & \multirow{2}{*}{$\begin{array}{l}\Delta \mathbf{H}^{\mathbf{0}} \\
\left(\mathbf{k J} . \mathrm{mol}^{-1}\right)\end{array}$} & \multirow{2}{*}{$\begin{array}{l}\Delta \mathbf{S}^{\mathbf{o}} \\
\left(\mathbf{k J} . \mathrm{mol}^{-1}\right)\end{array}$} & \multicolumn{3}{|c|}{$\Delta G^{0}\left(K_{J} \cdot m^{-1}\right)$} & \multirow[t]{2}{*}{$\mathbf{R}^{2}$} \\
\hline & & & $300 K$ & 315K & 330K & \\
\hline 500 & 34.371 & 0.1227 & -2.4260 & -4.2659 & -6.1057 & 0.977 \\
\hline 700 & 31.346 & 0.1117 & -2.1758 & -3.8519 & -5.5280 & 0.999 \\
\hline 1000 & 29.246 & 0.1024 & -1.4849 & -3.0214 & -4.5580 & 0.992 \\
\hline 1200 & 27.541 & 0.0956 & -1.1374 & -2.5713 & -4.0051 & 0.992 \\
\hline
\end{tabular}


750

751 Table 6

\begin{tabular}{|c|c|c|c|}
\hline Adsorbant & Tempruture & $\mathrm{Q}(\mathrm{mg} / \mathrm{g})$ & Reference \\
\hline \multirow[t]{3}{*}{ Ox- FVESP } & $27^{\circ} \mathrm{C}$ & 1111.11 & This study \\
\hline & $42{ }^{\circ} \mathrm{C}$ & 1250.00 & \\
\hline & $57^{\circ} \mathrm{C}$ & 1428.57 & \\
\hline Granular Activated Charcoal & & 57.47 & {$[1]$} \\
\hline Animal bone-derived activated carbon & & 28.04 & [13] \\
\hline Corncob derived activated carbon & & 26.00 & {$[13]$} \\
\hline Coconut shells derived activated carbon & & 23.25 & [12] \\
\hline Modified activated carbonaceous materials & & 100,00 & {$[14]$} \\
\hline \multirow[t]{4}{*}{ Zinc chloride Ocimum basilicum leaves powder } & $25^{\circ} \mathrm{C}$ & 588.235 & {$[35]$} \\
\hline & $35^{\circ} \mathrm{C}$ & 625.000 & \\
\hline & $45^{\circ} \mathrm{C}$ & 666.667 & \\
\hline & $55^{\circ} \mathrm{C}$ & 714.286 & \\
\hline
\end{tabular}

